\title{
THE BIRDS OF TRISTAN DA CUNHA.
}

\section{By GREGORY M. MATHEWS, with Notes By J. G. GORDON.}

TRISTAN DA CUNHA is the general name for a group of three small volcanic islands belonging to Great Britain, situated in the South Atlantic; the summit of the largest being in $37^{\circ} 5^{\prime} 50^{\prime \prime}$ South by $12^{\circ} 16^{\prime} 40^{\prime \prime}$ West.

They were discovered in 1506 by the Portuguese admiral, Tristan (or Tristão) da Cunha (1460-1540), who was nominated first Viceroy of Portuguese India in 1504, but owing to temporary blindness was unable to serve ; he was, however, placed in command of a fleet which operated on the east coast of Africa. After discovering the islands which now bear his name, he visited Madagascar, Mozambique, Brava and Sokotra.

Dutch vessels brought back reports on the islands in 1643 ; and in 1656 Van Riebeck, the founder of Cape Town, sent a ship from Table Bay to Tristan to see if it was suitable for a military station. Later in the seventeenth century ships were sent from St. Helena by the English East India Company, with the idea of forming a settlement.

A British naval officer visited the group in 1760 and named Nightingale Island.

John Patten and his erew lived on Tristan from August 1790 to April 1791.

The first permanent inhabitant, however, was Thomas Currie, who landed there in 1810. Later an American named Lambert and another man named Williams made Tristan their home, till they were drowned in May 1812.

During the war between the United States and Great Britain, the islands were largely used as a base by American cruisers, sent to prey on British merchant ships. This and other considerations urged by Lord Charles Somerset, Governor of Cape Colony, caused the islands to be taken possession of as a dependency of the Cape. The formal proclamation of annexation was made on August 14 th, 1816.

A military detachment consisting of about fifty men, with a eaptain, two subalterns and a medical officer, left the Cape in the s.s. Falmouth on November 2nd, 1816, with the necessary equipment of eattle and agricultural implements. Owing to adverse winds they did not arrive on Tristan till the 28 th of the month. This small garrison was maintained there till November 1817.

At their own request William Glass, a corporal of the Royal Artillery, with his wife and two children and two masons, were left behind, and these began the present settlement. In 1827 five coloured women from St. Helena were induced to migrate to Tristan to become the wives of the five bachelors. Later, coloured women from Cape Colony married residents on the island. Other settlers are of Dutch, Italian and Asiatic origin. The settlement was on the plain on the northwest of the island of Tristan da Cunha.

Over the community Glass (1817-53) ruled in patriarchal fashion. After Glass came Cotton, whe was succeeded by Green. They now manage their own affairs without any written laws, the project once entertained of providing them with a formal constitution being deemed unnecessary.

Gough Island, or Diego Alvarez, discovered by the Portuguese in the sixteenth 
century, has been claimed as a British possession since the annexation of Tristan. It lies 250 miles S.S.E. of this group. It was called by its present name after Captain Gough, the commander of a British ship which visited it in 1731. The birds of Gough Island were worked up by Clark in the Ibis for 1905, p. 247 et seq., and, of course, are not included in this article.

The Tristan group lie in lat. $37^{\circ} 2^{\prime} 48^{\prime \prime}$ South; long. $12^{\circ} 18^{\prime} 20^{\prime \prime}$ West. From the Cape of Good Hope they lie westward 1,550 miles and about one-third farther from Cape Horn, lying nearly on a line drawn between the two capes. They lie 1,320 miles south of St. Helena. In October 1873 the islands were carefully surveyed by the Challenger.

The islands rise from the submarine elevation which runs down the middle of the Atlantic. The depth between the islands is in some places over 1,000 fathoms.

Tristan, the largest and northernmost island, has an area of $16 \mathrm{sq}$. miles, is nearly circular in form, about 7 miles in diameter, and has a volcanic cone (7,640 ft.), usually capped with snow, in the centre. Precipitous eliffs, 1,000 to $2,000 \mathrm{ft}$., rise from the ocean on all sides, except the north-west, where there is an irregular plateau of about $12 \mathrm{sq}$. miles, $100 \mathrm{ft}$. above the sea. A stream crosses the northern end of the plateau, falling over the cliff in a fine cascade. The crater of the central cone contains a fresh-water lake about 150 yards in diameter. This and other erater lakes are said never to be frozen over.

InaCCESSIBLe Island, the westernmost of the group, is about 20 miles from Tristan. It is quadrilateral in form, the sides being about 2 miles long, with cliffs about $1,000 \mathrm{ft}$. Its highest point $(1,840)$ is on the west. At the base of the cliffs in some places are narrow fringes of beach.

Nightingale Island, the smallest and most southern of the group, is 10 miles from Inaccessible Island. Its area is not more than $1 \mathrm{sq}$. mile. Its coasts, unlike those of the other two islands, are surrounded by low cliffs, from which there is a gentle slope up to two peaks $(1,100 \mathrm{ft}$. and $900 \mathrm{ft}$. high). There are two small islets, Stoltenhoff (325 ft.), called after two brothers of this name, marooned on Inaccessible Island, and Middle (150 ft.), and several rocks adjacent to the coast.

The rocks of Tristan da Cunha are basalt, porphyritic basalt, dolerite, augiteandesite, palagonite, volcanic tuff and ashes. A block of gneiss in the crater indicates a continental foundation of the island. The caves in Nightingale Island indicate that it has been elevated several feet. On almost all sides the islands are surrounded by a broad belt of kelp (Macrocystis pyrifera), through which a boat may approach the rocky shores even in stormy weather. There is no good anchorage in rough weather.

The prevailing winds are westerly. December to March is the fine season. The climate is mild and on the whole healthy, the temperature averaging $68^{\circ}$ Fahr. in summer, $55^{\circ}$ in winter, sometimes falling to $40^{\circ}$. Rain is frequent; hail and snow fall occasionally on the lower ground. The sky is usually cloudy. The islands have a cold and barren appearance. The tide rises and falls about $4 \mathrm{ft}$. The greatest known depth of the ocean is midway between the islands of the Tristan group and the mouth of the Rio de la Plata. The bottom was here reached at a depth of $46,236 \mathrm{ft}$., or $8 \frac{3}{4}$ miles, exceeding by more than $17,000 \mathrm{ft}$. the height of Mt. Everest. 
The first published account of the natural productions of this group appears in the Trans. Linn. Soc. (Lond.), vol. xii, p. 483 et seq., 1818. The paper was read before the Society on December 16th, 1817, by Captain Dugald Carmichael. This naturalist went with the expedition in November of 1816 and stayed till March 30th, 1817. He explored Tristan and gave an excellent description of the formation, etc. On January 4th, 1818, he, together with Dr. Evers and their servants and a guide, ascended the peak. On their return they encounted four species of Albatross which breed on the island, viz. Diomedea spadicea, ${ }^{1}$ exulans, chlororynchos and fuliginosa. This author is the first to describe the nesting of Phoebetria fusca. He also described the nest of Thalassarche chlororhynchus. Of this latter bird he says that "it builds its solitary nest in some sheltered corner, selecting in particular the small drains that draw the water off the land into the ravines. There it runs up its nest to the height of ten or twelve inches, of a cylindrical form, with a small ditch round the base. A curious circumstance with regard to this bird is, that when irritated the feathers of its cheeks are separated so as to display a beautiful stripe of naked orange skin, ${ }^{2}$ running from the corners of the mouth towards the back of the head.

"They nourish their young by disgorging the contents of their stomach. We could not help admiring the utter unconsciousness of danger displayed by them on our approach. Their plumage is in the finest order, copious and without the slightest stain. They find great difficulty in getting on wing and must run twenty or thirty yards along the ground with expanded wings before they can get fairly under way."

Of Phoebetria fusca he says they are "at this season (January) gregarious, building their nests close to each other. In the area of half an acre I counted upwards of a hundred. They are constructed of mud raised five or six inches, and slightly depressed at the top. At the time we passed, the young birds were more than half grown, and covered with a whitish down. There was something extremely grotesque in the appearance of these birds standing on their respective hillocks motionless like so many statues, until we approached close to them, when they set up the strangest clattering with their beaks, and if we touched them squirted on us a deluge of fœid oily fluid from the stomach."

He mentioned a species of Thrush, Turdus guianensis (=Nesocichla eremita), a Bunting, Emberiza brasiliensis (= Nesospiza acunhae) and a Moor-hen, Fulica chloropus (= Porphyriornis). These birds have spread over the whole island, and are found on the tableland as well as on the low ground. The Fulica conceals itself in the wood, where it is occasionally run down by the dogs ; the others fly amongst the cantonment.

$\mathrm{He}$ also mentioned that there are six species of Procellaria, but only names Macronectes giganteus, Adamastor cinereus and Pachyptila vittata (keyteli).

He increased his list by adding Catharacta antarctica, Sterna vittata ( = varies very little from $S$. hirundo) and Anous stolidus, and he brings his total up to fourteen by the inclusion of Aptenodytes chrysocoma (=Eudyptes cristatus moseleyi).

Thus a list of the birds of Tristan containing fourteen species was started in 1818.

1 Can spadicea be meant for melanophris?

2 At the Natural History Museum on the 29 th April, Mr. E. F. Stead, of New Zealand, told me that this exposed orange skin was a continuation of the gape, and that these birds could open their bill as wide as at an angle of 90 degrees. 
The Challenger surveyed the group in 1873, and the birds collected then and during the famous cruise were worked up by Sclater, in the Proc. Zool. Soc. Lond. for 1878, and this was again printed and many birds figured in part viii, Report on the Birds of the Challenger, 1881.

The two land birds depicted are Nesocichla eremita, pl. xxiii, and a figure of the bill, foot and wing given on p. 111; and Nesospiza acunhae, on pl. xxiv, and a cut of the head, foot and wing given on p. 112.

In the Proc. Zool. Soc. Lond. 1861, p. 260, pl. xxx, Sclater had added the Tristan coot, Gallinula nesiotis.

To the list of fourteen the Gallinula was added, and Megalopterus (as Anous melanogenys), Pelagodroma marina and Oestrelata mollis, making now a total of eighteen.

The only Penguin from Tristan was figured on pl. $\mathrm{xxx}$ and worked up on p. 128.

Moseley, Notes by a Naturalist, 1892, p. 115, adds that Daption capensis and Macronectes breed on Tristan, and that Procellaria glacialoides was also obtained $(=$ Priocella antarctica $)$. Total twenty.

From Inaccessible Island, Moseley writes of Eudyptes: "All night the penguins were to be heard screaming on shore and about the ship, and as parties of them passed by, they left vivid phosphorescent tracks behind them as they dived through the water alongside."

$\mathrm{He}$ comments on the action of these birds in the water : " they showed black above and white beneath, and came along in a shoal of fifty or more from seawards towards the shore at a rapid pace, by a series of successive leaps out of the water, and splashing into it again, describing short curves in the air, taking headers out of the water and headers into it again, splash, splash went this marvellous shoal of animals, till they went splash through the surf on to the black stony beach and there struggled and jumped up amongst the boulders and revealed themselves as wet and dripping penguins.

"In penguin rookeries the grass covers wide tracts with a dense growth like that of a field of standing corn, but denser and higher, the grass reaching high over one's head. The millions of penguins sheltering and nesting amongst the grass saturate the soil on which it grows with the strongest manure, and the grass, thus stimulated, grows high and thick and shelters the birds from wind, rain and enemies, such as the predatory gulls.

"The sulphur plumes lie close to the head when the bird is swimming or diving, but they are erected when it is on shore, and seem then almost by their varied posture to be used in the expression of emotion, such as inquisitiveness and anger.

"The bill is bright red and very strong and sharp at the point ; the iris is also red. The iris is remarkably sensitive to light; they feed at sea at night as well as in the daytime.

"Most of the droves of penguins make for one landing-place, where the beach was covered with a coating of dirt from their feet, forming a broad track, leading to a lane in the tall grass about a yard wide at the bottom, and quite bare, with a smoothly beaten black roadway ; this was the entrance to the main street of this part of the 'rookery.'

"Other smaller roads led at intervals into the rookery to the nests near its border, but the main street was used by the majority of birds. It is called 'rock- 
hopper,' from its curious mode of progression. The birds hop from rock to rock with both feet placed together.

"Naturally going through this horde of nesting birds was very difficult, as owing to the high grass one cannot see far and the 'roads' join and bifurcate in all directions. The stench is overpowering and the yelling of the birds perfectly terrifying. The nests are placed so thickly together that you cannot help treading on eggs and young birds at almost every step.

"'A parent bird sits on each nest with its sharp beak erect and open ready to bite, yelling savagely 'caa-caa-urr-urr,' its red eye gleaming and its plumes at half-cock, and quivering with rage. No sooner are your legs within reach than they are furiously bitten, often by two or three birds at once. Naturally your progress is slow and painful. The air is close in the rookery and the sun hot above.

"These penguins make a nest which is simply a shallow depression in the black dirt, scantily lined with a few bits of grass or not lined at all.

" They lay two greenish-white eggs, and both male and female incubate, in October, when eggs and young are found. The breeding season is probably September to November.

"One of the most remarkable facts about the penguins is that they are migratory ; they leave Inaccessible Island in the middle of April after moulting, and return, the males in the last week in July, the females about August 12th."

Moseley, loc. cit., on p. 105, from Inaccessible Island comments on the extreme tameness of the Thrush (Nesocichla) and the Finch (Nesospiza). The Thrushes could be knocked over with a stick, but they were not so tame as those on Tristan. The Finch seems to be extinct on Tristan.

Of the Porphyriornis on Inaccessible Island, he says that it is much smaller than the Tristan form, with finer legs and a longer beak. This is true, as the bird is Atlantisia rogersi Lowe.

"On this island also the noddies, Megalopterus, were sitting on the tree-tops with the thrushes. These noddies breed also in St. Paul's Rocks in the Atlantic in August, when young and eggs were found. The nests were made of green seaweed (Caulerpa clavifera), which grows on the bottom in the bay and around the rocks, and which, getting loosened by the surf, floats and is picked up by the birds on the surface. The weed is cemented together by the birds' dung, and the nests, having been used for ages, are now solid masses, with a circular platform at the summit, beneath which hang down a number of tails of dried seaweed. The older nests project from the cliffs on the sheltered side of the rocks, like brackets, having been originally commenced, as may be seen by the complete graduations existing, by a pair of birds laying an egg (always single) on a small projecting ledge of rock and adding a few stalks of weed.

"It is only the stronger and more vigorous noddies that are able to occupy and hold possession of a nest of this description.

"Prions and other sea birds have riddled the peaty ground underneath the trees in the Phylica wood in all directions with their holes. The burrows are about the size of large rats' holes and they traverse the ground everywhere, twisting and turning and undermining the ground, so that it gives way at almost every step."

Still on Inaccessible Island he says that Catharacta antarctica were plentiful. "These predatory gulls were quarrelling and fighting over the dead bodies of 
penguins. They quarter the ground when hunting, and when there is a kill assemble in numbers in the same curious way as vultures. They steal eggs, but their chief food is the prions, which they sometimes even draw from their burrows.

" On Nightingale Island the penguins were nesting in the tall grass, very much in the same way as those on Inaccessible Island. This island is the only one where there are caves; these are so numerous as to form a striking feature.

"Here the Yellow-billed Mollymawk (chlororhynchus) made numerous nests amid the thousands of penguins' nests in the long grass. The ground of the rookery is bored in all directions by the holes of prions and petrels, which thus live under the penguins. Their holes are not so numerous in the rookery at Inaccessible Island as here. The holes add immensely to the difficulties of traversing a rookery, since when the ground gives way a fall into the black filthy mud amongst a host of furious birds, which have then full chance at one's eyes and face, is far from pleasant. One or two skuas also nested in the rookery. Truly a medley of birds. The skuas lay two eggs. There are about 400,000 penguins on Nightingale Island."

Wilkins [4] says that he collected between May 28th and June 1st, 1922, the eggs of Thalassarche chlorhynchus, Ardenna gravis, Eudyptes cristatus and Catharacta antarctica. He also reports that Diomedea exulans, which used to breed on Tristan, is now only rarely found on Inaccessible Island. Phoebetria fusca nests in August and young birds leave the nest in April. P. palpebrata were hatched on January 15th at South Georgia.

Thalassarche chlororhynchus nests in August; young leave the nest in April. $T$. chrysostoma were hatched on January lst, at South Georgia.

Pterodroma macroptera moults in May and lays in July.

Pterodroma brevirostris? lays in November.

Pachyptila vittata keyteli lays in September.

Catharacta antarctica lays in September.

Sterna vittata lays in November.

Anous stolidus arrives in September and lays in November, but goes away for the winter.

Eudyptes cristatus moults in March and leaves the island and comes again in August and lays its eggs in September.

Lowe [5] describes some new forms from this group, and on p. 522 gives a drawing of the head and wings of two Nesospiza. He also discussed the genus Nesocichla and gives text figures on pp. 526-7.

Apart from the foregoing works, the following should be consulted, as they bear upon the ornithology of the South Atlantic.

1. Clarke, Ibis, 1905 (April), pp. 247-68. " On the Birds of Gough Island."

2. Clarke, Ibis, 1906 (January), pp. 145-87. " "On the Birds of the South Orkney Islands."

3. Clarke, Ibis, 1907 (April), pp. 325-49. "On the Birds of the Weddell and Adjacent Seas, Antarctic Ocean."

4. Wilkins, Ibis, 1923 (April), pp. 474-511. " Report on the Birds collected during the Voyage of the Quest" (pp. 495-501).

5. Lowe, Ibis, 1923 (April), pp. 511-29. "Notes on Some Land Birds of the Tristan da Cunha Group, collected by the Quest Expedition" (pp. 519-29). 
6. Lowe, Ibis, 1928 (January), pp. 99-131. "A monograph on Atlantisia rogersi : The Flightless Tristan Rail."

7. Lowe and Kinnear, British Antaretic (Terra Nova) Expedition, 1910. Zoology, vol. iv, no. 5, pp. 103-93, "Birds, September 1930."

8. Stenhouse, Scottish Naturalis, 1924, pp. 93-6, "Notes on Rare Land Birds from Tristan d'Acunha in the Royal Scottish Museum, Nesospiza acunhae."

9. Oliver, New Zealand Birds, 1930.

10. Kinghorn and Cayley, Emu, vol. xxii, pp. 81-96, October 1922.

11. Bent, Life Histories, North American Petrels, etc., 1922.

12. Rogers, The Lonely Island, 1926.

The following is a list of the birds made by P. C. Keytel on Tristan da Cunha, kindly sent me from the South African Museum by the Director, Dr. E. L. Gill. They are now in the South African Museum.

Eudyptes cristatus (with eggs).

Diomedea exulans (with egg).

Thalassarche chlororhynchus (with egg and photograph of bird on nest).

Phoebetria fusca (with egg).

Pterodroma macroptera.

Ardenna gravis.

Pachyptila vittatus (broad-billed) (with egg).

Catharacta antarctica (with egg).

Sterna vittata (with eggs), adult and juvenile.

Anous stolidus (with egg).

Porphyriornis nesiotis, adult and juvenile.

Nesospiza acunhae.

Nesocichla eremita, adult and juvenile.

Atlantisia rogersi-not in Keytel's collection, but two specimens obtained by

South African Museum in 1932. Also Fregettornis grallaria.

Note.-I hear that about fifteen specimens of this Rail have been sent to different museums in America. It is sincerely to be hoped that the bird will not be exterminated by any evil-disposed person for the sake of money.

\section{UP-TO-DATE LIST OF THE BIRDS OF TRISTAN DA CUNHA.}

The page numbers represent the page in Syst. Av. Aethiop. Sclater.

P. 3. *†Eudyptes cristatus moseleyi-Rock Hopper Penguin.

P. 5. Oceanites oceanica oceanica-The Yellow-webbed Storm Petrel.

P. 6. *Pelagodroma marina marina-The White-faced Storm Petrel.

P. 6. ? [Garrodia nereis chubbi-Falkland Island Grey Storm Petrel.]

P. 7. ? [Fregetta melanogaster-Black-bellied Storm Petrel.]

$* \dagger$ Fregettornis grallaria - White-fringed Storm Petrel.

Fregettornis melanoleuca-Black and White Storm Petrel.

P. 8. *†Puffinus assimilis elegans - Gough Island Shearwater.

P. 9. * $\dagger$ Ardenna gravis - Greater Shearwater.

P. 10. Priocella antarctica-Silver-grey Petrel.

*?† Adamastor cinereus - Great Grey Shearwater.

* Tristan breeding birds.

$\dagger$ Gordon collection. 
P. 11. ? [Procellaria aequinoctialis - Cape Hen.]

*†Pterodroma macroptera-Long-winged Petrel.

$* \dagger$ Pterodroma incerta-Atlantic Petrel.

$\dagger$ Pterodroma externa - Juan Fernandez Petrel.

*+Pterodroma mollis - Soft-plumaged Petrel.

P. 12. ? [Pterodroma brevirostris -Kerguelen Petrel.]

P. 13. Daption capensis - Cape Pigeon.

${ }^{*}+$ Pachyptila vittata keyteli-Tristan Broad-billed Prion.

P. 14. Macronectes giganteus - Giant Petrel.

P. 15. *Pelecanoides urinatrix dacunhae-Tristan Diving Petrel.

*†Diomedea exulans exulans - Wandering Albatross.

P. 16. †Thalassarche melanophris-Black-browed Mollymawk.

*†Thalassarche chlororhynchus-Yellow-nosed Mollymawk.

P. 17. *†Phoebetria fusca-Sooty Albatross.

P. 104. *†Atlantisia rogersi-Tristan Rail.

P. 109. *Porphyriornis nesiotis - Tristan Coot (extinct?).

P. 144. *?† Larus dominicanus-Southern Black-backed Gull.

P. 147. *+Catharacta antarctica-Antarctic Skua.

P. 149. *†Sterna vittata-Kerguelen Tern.

P. 154. *†Anous stolidus-Atlantic Noddy.

P. 155. *Megalopterus minutus atlanticus-Atlantic White-capped Noddy.

P. 447. *†Nesocichla eremita eremita-Tristan Thrush.

$*+N$ esocichla eremita gordoni-Inaccessible Island Thrush.

P. 833. *Nesospiza acunhae acunhae-Tristan and Inaccessible Island Bunting.

*Nesospiza acunhae questi-Nightingale Island Bunting.

*Nesospiza wilkinsi-Large-billed Bunting (Nightingale Island).

P. 844. †Ionornis martinica-American Purple Gallinule.

Total thirty-six, of which twenty-two at least breed in the group.

In the following compilation I have endeavoured to bring together the main items of interest in the life history of those birds which have been recorded from this group of islands, together with the history of the discovery of the islands and subsequent occupation, taken from the published accounts.

Mr. Jack G. Gordon's notes are in square brackets.

[At all times, but especially when the potato crop fails, and supplies run low, the islanders depend largely on the various sea-birds and their eggs for food. All the species frequenting the islands, with the exception of Skuas and Penguins, are eaten, as are all eggs, those of the Penguin and Yellow-nosed Albatross easily outnumbering all the rest put together. Unfortunately the people are careless, and take no thought or care to conserve this very valuable source of supply, so several species have become scarce or have left the island. Both Mrs. Barrow and Mrs. Rogers give several instances of wholesale destruction, no less than 6,939 "Mollyhawks" being killed during March and April in one year " and 25,200 Penguins' eggs being taken in one season." On the 12th January, 1909, Mrs. Barrow writes: "Six men who had been to Inaccessible returned, and I am sorry to say that one of them purposely set fire to the tussac grass, which has been burning for three days. The fire can be seen from here 25 miles away. The men say that thousands of birds must have been destroyed, 
as it is their nesting time. It is horrible to think of." She adds that it was still burning a month later! Acts like this should be severely punished. At that time several men of a bad type came from Cape Town and caused much trouble in the generally peaceful community.

Also a great many dogs were kept, some families having as many as four, most of which had to find their own living, and the birds suffered in consequence. But this has been remedied. Until 1882 there were no rats on Tristan, but that year half a dozen managed to get ashore from the wreck of the Henry B. Page. Mr. Dodson, the missionary then, urged the men to kill them, pointing out what trouble they would cause. But they thought a few rats wouldn't hurt, and did nothing! In later years these rats wrought great havoc among the crops, and were probably the cause of all the land birds becoming extinct on the island.

Seemingly there are no rats yet on either Inaccessible or Nightingale Islands, and long may it continue so.

I had wished to get into touch with Tristan, and learn something of its birds. But it is well named "the lonely isle," for my first letter, written in 1910 and addressed simply to "the Chief man, Tristan da Cunha, S. Atlantic" took five years to get there! and three more for an answer to reach me! There were then letters from three "Chiefmen" and one "Chiefwoman." I have since received occasionally rough skins, and eggs (mostly broken), but many seem to go astray on the long journey. All are of great interest, several being first records for the group. The chief difficulty has been to get any data with the specimens. Though I have sent out scores of data cards, some already written up as guides, it seems impossible for them to do it correctly, and some of their efforts are very quaint. Here are some samples. "Mollyhawk egg, from Franks Hill, North West Point of Tristan da Cunha. We name this hill after a man by the name of Frank who got lost on the mountain and he made his house on the mountain and slept there, and we call it Franks Hill." Nothing about the bird, nest or anything! "The Peho egg, a blackbird with yellow on the beak. This bird make the nest near the edge of cliffs and it is very dangerous to get at their nests at times." This is a bit better. "These 6 eggs shell are call the 'Seahen,' we got them on the 14th of October 1920, and my boy had to go 9 miles for them and my boy's name is William and he is thirteen years of age and we got them the place we call Sandypoint." Too much William and not "Seahen " about this effort!

Almost all the skins are now in the Royal Scottish Museum, Edinburgh, and were verified by W. Eagle Clarke and Surgeon-Admiral T. H. Stenhouse. Gregory M. Mathews has also examined some of them.

I am greatly indebted to the books on the island, by Mrs. Barrow and Mrs. Rogers, for much information regarding the birds and islands.]

\section{EUDYPTES CRISTATUS MOSELEYI M. \& I. The Rock-hopper Penguin (Penguin).}

Eudyptes serresianus moseleyi Mathews and Iredale, Man. Birds Austr. vol. i, p. 11, March 9th, 1921. Inaccessible Island, Tristan da Cunha Group.

This species has a very wide range, extending from Prince Edward, Marion, Crozets, Kerguelen and Gough Islands: Tristan da Cunha to the Austro-New Zealand Region.

1 The second name given in a few instances is the name by which the Tristan islanders call the bird. 
The typical form is from the Falkland Islands (figured in Cim. Phys. pl. 49). It is represented by this subspecies in the Tristan Group, which is figured in Voy. Chall. pl. 30, 1881, and on Kerguelen by interjectus; while the AustroNew Zealand subspecies must be called filholi, which I have figured and described in my Birds of Norfolk and Lord Howe Islands, pl. 32, 1928. The older-used name was chrysocome, but this is now considered indeterminable by up-to-date workers.

It spends a lot of its time at sea, only coming ashore to breed. It moults in March, then goes to sea in the middle of April, returning again in July or August. Mates, and commences nesting in September. In October eggs and young are found, and by November all or most of the eggs have been hatched.

The Austro-New Zealand form leaves Macquarie Island early in May, after moulting in April, and returns about the middle of October, and its breeding season is October to December.

They nest in colonies, in the long grass, making a nest which is just a depression, sometimes lined.

The eggs consist of two to the clutch, and are bluish white to greenish white, ovoid in shape and with a smooth surface, but pitted, and measure 65.5 by 56.5 $\mathrm{mm}$. (Macquarie Island) and 70 by $\mathbf{5 7 \cdot 5}$ (Campbell Island) (Oliver 9 ).

The breeding season is September to November.

[They are very numerous in the group, and at Tristan there are large rookeries, at "Stony Beach," "Trypot," "Seal Bay," "Sandy Point," etc., where they nest close to the sea, as a rule.

Last year young come in to moult in December, and Mrs. Barrow writes in January 1908: "The poor penguins that land on this shore (i.e. near the settlement) have but a short life, as the dogs hunt them out at once. While moulting they need no other food than that which Nature has provided in a store of oil from which they can draw. They hide in holes, small caves, etc., during the time they are helpless."

The eggs are a great asset in hard times, but Mrs. Rogers states that the birds themselves are not eaten by the people. On the 24th September, 1906, Mrs. Barrow writes: "The men again went to Sandy Point for eggs. I wish they did not take them in such a wholesale way. They brought back shoals!" While on the 19th September, 1907, she says: "The men went to the Penguin rookery to-day. Each man carries a box on his back holding 150 eggs, no light load ! When the birds are up for laying, the pairs keep together, the hen on the nest, and the cock standing by. They make a tremendous noise day and night. While in 1924 Mrs. Rogers records that Penguin eggs are used in great quantities in September and October, and that 25,200 were said to have been used that year, 7,200 being collected by the boats in a day round the island. While on the 21 st September, 1925, 5,000 were collected. Little, if any, nest is made, and two eggs are the usual clutch, but they will lay several if the first are taken when fresh. The eggs are white, with a tinge of blue, and rather spherical in shape, and are often much stained, when the rookery is in peaty or damp ground. They vary greatly in size. My two largest sets taken 14/9/17 and 8/9/20 measure $72 \times 57.5$ and $71.5 \times 55.5$, and $72.5 \times 57$ and $70 \times 55$. While the smallest taken $8 / 9 / 20$ is only $58.5 \times 48$ and $57.5 \times 47$. One egg taken $5 / 9 / 20$ and "first egg the Penguin lay" measures $63.5 \times 44$ and is unlike a Penguin's in shape, being elongate and pointed.

Of Nightingale Island the Rev. H. M. Rogers says, 31st January, 1924 : "The 
1,000 's of Penguins in their rookeries are a truly remarkable sight. Though moulting, they were fat and lively, but we noticed many dead young, and numbers of spoiled eggs. They nest right up, far ashore, here in the Tussac, which grows taller than a man. Nothing molests them-men, rats, cats and dogs are all absent." There are large rookeries, too, on the small adjacent islets- "Alec's,"

"White," "Stoltenhoff," and "Old Man." I have received several skins at various times.]

\section{GARRODIA NEREIS CHUBBI Mathews. Falkland Grey-backed Storm Petrel.}

This bird flies the southern oceans. It is figured by Godman in his Monograph, pl. 14, 1907. It is represented in the South Indian Ocean by the Kerguelen form, couesi, and the typical form occurs in the South Pacific Ocean in the Austro-New Zealand region. This latter bird is figured by Gould, vol. vii, pl. 64, 1845, and by myself in vol. ii, pl. 69, 1912.

\section{PELAGODROMA MARINA MARINA (Lath.). White-faced Storm Petrel.}

This bird was originally described from the mouth of the Rio de la Plata, where it was collected, and a drawing made by Sidney Parkinson. It breeds on Nightingale Island.

There are four or five forms, the above being the typical subspecies ; it is represented by hypoleuca breeding on the Great Salvage, Canary and Cape Verde Islands. The Australian form is dulciae, figured in my Birds Austr., vol. ii, pl. 70, 1912, and the New Zealand bird maoriana, figured by Godman in his Monograph, pl. 15, 1907.

The nest is placed at the end of a burrow.

The clutch is one; variable in size and shape. Sometimes pure white, at others the larger end is thickly speckled with minute rusty spots and others sparsely all over. Elongately oval to subrotundately oval. The measurements are $35-41 \mathrm{~mm} . \times 25-28$.

Bent [11] gives the average of the typical form as $36 \cdot 20 \times 22 \cdot 03$.

Breeding season November to January.

[In the Systema Aethiopica, vol. 1, 1924, this petrel is described as breeding at Nightingale Island. While Alexander's Birds of the Ocean, 1928, also records it from Tristan. I have not received any Tristan skins, nor have I had any information from the natives regarding this kind. But they easily overlook species at all similar.

Eggs of the typical form are lacking in my collection, but two from Mud Island, Victoria, of $P$. $m$. dulciae, the Australian form, measure $38.9 \times 25$ and $37 \times 27 \cdot 5$. They are rather oval, and white with fine pale-red dots. Nest in a small burrow.]

\section{OCEANITES OCEANICUS OCEANICUS (Kuhl.). Yellow-webbed Storm Petrel.}

The bird breeds on Kerguelen and other islands in the Southern Ocean, such as the South Orkneys. Wanders north to Africa and Queensland in Australia. Europe.

The typical form was collected off the mouth of the Rio de la Plata, in South America. It was figured by Gould in vol. vii, pl. 65, 1846; Godman, in his 
Monograph, pl. 12, 1907, and I figured the Austro-New Zealand subspecies, in my Birds of Austratia, vol. ii, pl. 68, 1912.

It nests (Clarke 2) on Laurie Island, in the South Orkneys, in the cliffs. A photo is given on pl. $\mathbf{x}$, where on December 11 th the first egg was obtained.

"There was no attempt at nest making; the egg was simply laid in a hollow in the earth in narrow clefts and fissures in the face of the cliff, under boulders and sometimes under stones, on the screes sloping from the foot of the precipice at heights varying from 20 to $300 \mathrm{ft}$. above sea-level. Sometimes the egg was placed very far in. The searcher could hear the low hollow whistle uttered every few seconds by the sitting bird. When eaught on the egg the birds brought up a reddish fluid, which issued both from the mouth and nostrils.

"In addition to the low whistle, these Petrels had a harsh screaming chuckle. These noises they kept up almost continuously after dark, especially on still nights.

"They appear to return year after year to the same nesting places, for both eggs and dead young birds of previous seasons were numerous in the tenanted holes containing the fresh egg.

" The eggs are elongated ovals, dull white, peppered with tiny dots of reddishbrown and underlying ones of lilac, mostly accumulated round one end, but occasionally sprinkled all over the surface. Eight eggs average $33.7 \times 24 \mathrm{~mm}$. The largest $36 \times 24$, and the smallest $32 \times 23$. Bent (11) gives the average as $32 \cdot 2 \times 23 \cdot 2$."

The Austro-New Zealand from exasperatus breeds at Cape Adare in January, where it forms a tunnel, at the end of which is an enlarged chamber, lined with feathers.

The clutch is one, elongated, dull white, sparingly dotted with reddish spots, and sometimes these spots form a ring round the larger end. They measure 33 $\times 23 \mathrm{~mm}$.

Lowe and Kinnear (7) give a text-figure and say that these birds fly very close to and along the contour of every little wave, with outspread wings, very seldom flapping, but every now and again dropping the feet to touch the water and then picking up some small crustacean (?) from the surface. The feet, when the bird is on the wing, project about three-quarters of an inch beyond the tail, giving the tail a cuneate form which it does not really possess, the tail being cut across more or less square. Dr. Wilson was impressed with the resemblance of this Petrel to a house martin.

[This species was observed near the group by the Quest Expedition in May 1922. But on questioning the people they were told that this Petrel was rarely seen at the islands.

I have only a single egg taken at Jason Island, Falkland Isles, on the 12th December, 1928, nest a few feathers under a boulder. It measures $34 \times 23$, and is dull white, with a ring of tiny reddish spots.]

\section{FREGETTORNIS GRALLARIA TRISTANENSIS. The Atlantic White-fringed Storm Petrel (or Storm Pigeon).}

Mathews, Bull. B.O.C. lii, p. 123, April 5th, 1932. Inaccessible Island.

This bird nests on Inaccessible Island, as reported by the Islanders, and this is the first record for the Atlantic Ocean. This and Pterodroma externa tristani 
occur on the Tristan Group. The question arises, what is the connection between Juan Fernandez Island in the Eastern Pacific and the Tristan Group?

The species is figured as Fregetta grallaria in my Birds of Australia, vol. ii, pl. 72, 1912, and in my Birds of Norfolk and Lord Howe Islands, pls. 6 and 10, 1928 .

In the American Museum Novitates no. 124, July 22nd, 1924, Dr. Robert C. Murphy proved that the type of grallaria did not come from Australia and restricted the type locality to the breeding form on Juan Fernandez Island. Now grallaria occurs commonly in the South Pacific Ocean, between Australia and South America, and we havethree forms there. Wing of typical birds $153.9 \mathrm{~mm}$. ; innominatus, $160 \cdot 8$; titan, 181.6. In the same publication no. 322 , July 14 th, 1928 , p. 4, Murphy named his large form, titan, when he had 17 males and 10 females; he found the females slightly exceed the males in size; in 63 skins measured from Juan Fernandez, the females also were slightly larger.

It was the finding of this species in the Atlantic, so near the type locality of leucogaster, that caused all the workers to mix up the two forms. A bird with white fringes to the feathers of the uppersurface and an all-white undersurface was to most men typical leucogaster; hence they called leucogaster short-toed, as this tristanensis is. Some workers speak of the short-toed leucogaster (=tristanensis) and the long-toed.

Writing of the typical form of grallaria, Bent (11), under leucogastris, quotes Beck as saying that it breeds on Santa Clara Island, which lies about ten miles from the west end of Masatierra Island. "The nests were usually in rock piles under a good-sized rock. The few nests examined were lined with straws or a few twigs from bushes. One nest with its downy occupant was plainly visible without moving the overshadowing rock. On January 19th, 1914, the date of my visit, I found more nests with young birds than with eggs. As with other species of petrels, the downy young is left alone during the day."

Eggs.-Clutch one. The eggs vary in shape from oval to broad elliptical ovate. The shell is smooth, but without lustre, and the colour is dull white, more or less discoloured. One has a wreath of small purplish-brown dots near the larger end, and in one these dots form a cap over the whole of that end ; the other has a larger cap of such dots with many minute dots scattered over the egg. The three measure $34.5 \times 24 ; 34 \times 25 ; 32.5 \times 25 \mathrm{~mm}$. (average $33.6 \times 24.66$ ).

Breeding season December and January (Juan Fernandez Group).

Juvenils.-The new plumage, which shows under the quaker drab-coloured down, is much like the adult plumage, except that the scapulars and the wingcoverts, particularly the latter, are broadly edged with white.

An interesting characteristic of this bird is the manner in which it strikes the water with one foot. In a breeze or wind it was always the leeward leg that was used, the windward one being stretched out behind. As our schooner was always on the wind, the Petrels usually had but little use for the leg on the southern side of the body. When the birds flew directly into the wind either one or the other or both legs might be used.

[Local name "Storm Pigeon." This species is well known to the people and is not uncommon in the islands. Two skins have been sent me, one of which is labelled "Inaccessible Island, 28th April, 1923." I do not know if it ever breeds on Tristan itself, but it is said to do so on either Inaccessible or Nightingale, or possibly both, though no eggs have been sent as yet. 
The egg is described as measuring $33.5 \times 25$, dull white in colour, slightly spotted with reddish brown at the larger end, while the nest is of dry grass in a burrow 18 in. long.]

\section{FREGETTORNIS MELANOLEUCA. Black and White Storm Petrel.}

This bird was said by Salvadori to be from Tristan da Cunha. So far it remains unique. Its equilateral-shaped foot shows it to be a Fregettornis, but the size of the foot prevents it being any known form other than itself.

As we have no material on which to form an opinion, we must leave it as it is, and establish it as a species, as I pointed out in my Birds of Norfolk and Lord Howe Islands, p. 9, October 16th, 1928.

\section{FREGETTA TROPICA MELANOGASTER (Gould). Black-bellied Storm Petrel.}

This subspecies was described by Gould, from the South Indian Ocean, and figured by him, vol. vii, pl. 62, 1847, and in my Birds Austr. vol. ii, pl. 71, 1912, and by Godman on pl. 17, 1907, from the South Indian Ocean, breeding on Kerguelen and the Crozets ; and the Austro-New Zealand bird is australis breeding on the Auckland Islands off New Zealand.

It breeds on Laurie Island in the South Orkney Islands, in December (Clarke 2), in a crevice in a rock, placed about $15 \mathrm{ft}$. above the sea-level. The female was sitting. The eggs measured $36 \times 25.5 \mathrm{~mm}$. The Kerguelen egg (clutch one) is dull white sparingly dotted all over with small pink dots and measures $37 \times 27 \mathrm{~mm}$.

The Austro-New Zealand form constructs a small burrow in the bare earth, about $18 \mathrm{in}$. long, at the end of which is an enlarged chamber, lined with a good handful of dried grass.

The clutch is one egg, which is elliptic, blunt at each end ; white with a pinkish tinge and a broad ring of maroon speckles in or above middle. The measurements are 38.5 by $27 \mathrm{~mm}$. (Oliver 9) ; 37 by 27 (Stead, June 13th, 1932).

Breeding season January and February, Auckland Island.

Lowe and Kinnear (7), pp. 126-8, go fully into the species, and doubt if melanogaster can be separated from tropica.

\section{PUFFINUS ASSIMIIIS ELEGANS G. and S. Gough Island Shearwater.}

In my Birds of Australia, vol. ii, pp. 50-71, pl. 73, 1912, I gave the full history of this species, and for the first time showing clearly the differences between assimilis and lherminieri, which up to then had been mixed up by all workers; later Dr. Murphy, in the Amer. Mus. Novit. No. 276, September 8th, 1927, also discussed these forms.

Godman, in his Monograph, pl. 36, 1908, figured the type skin of elegans, which had already been figured by Salvin in Rowley's Miscell., pl. 34, in 1876. The type came from S. Lat. $43^{\circ} 54^{\prime}$; E. Long. $9^{\circ} 20^{\prime}$.

It was found breeding (Clarke 1) on Gough Island. The nesting burrows were deep and situated on the steep grass-covered bank flanking the side of the ravine. The locality was honeycombed with their holes.

The typical bird's egg (the clutch is single) is white, oval in shape, smooth and without gloss, and the average measurements are $50 \times 35 \mathrm{~mm}$. 
[This form was found breeding on Gough Island by the Scotia Expedition.

It seems little known in the Tristan Group, however, but a single skin was found in the collection sent in 1919, which is possibly the first record for the island. With it was an egg said to be of the same species, taken from a burrow, but with no data. It is oval and white and measures $51 \times 35 \cdot 8$.

I have two eggs of the typical form taken at Lord Howe Island on the 30th July, 1929. They are smooth, pure white and rather oval, and measure $50 \times$ $35 \cdot 3$ and $48 \times 33$; while two of the form $P$. a. kermadecensis from the Kermadecs are $50.8 \times 33.2$ and $49 \cdot 8 \times 35 \cdot 8$.]

\section{[PUFFINUS LHERRMINIERI. Brown-backed Little Shearwater.}

Bent (11), under lherminieri of Lesson, says that the birds breed in colonies in holes or crevices of the rocks, but seldom more than a foot from the surface.

The single egg is laid on the rock or in a loosely constructed nest of twigs or dried grass.

The egg is white, fragile and not highly polished. The average measurements are $52.5 \times 36.2 \mathrm{~mm}$. The four extremes measure $57 \cdot 3 \times 40 \cdot 8,49 \cdot 2 \times 35 \cdot 2$, $50 \times 34 \mathrm{~mm}$.

The breeding season on the Bahama Islands is April.

Incubation is carried on by both parents, and before the egg is laid both occupy the hole together. The parent does not brood the young, but merely sits beside it during the first day or two of its existence, after which it is left alone during the daytime.

This species does not occur in Tristan, but is added for comparison.]

\section{ARDENNA GRAVIS (O'Reilly). Greater Shearwater (Petrel).}

This bird is figured by Godman in his Monograph, pl. 25, 1908. It flies the Atlantic Ocean from Greenland to South Africa and South America.

On Nightingale Island Wilkins (4) says that many burrows of this bird were dug out, but in May they showed no sign of mating.

They breed on both Nightingale and Inaccessible Islands in November, where at night they flock in by the hundreds. A few were caught in their burrows.

Bent (11) says that this bird is called the hag, hagdon or hagdown by sailors. He quotes Jourdain, who describes the eggs (the clutch is single) as white, with no trace of markings, though slightly stained by the soil. The shape is a pointed oval ; and they are entirely devoid of gloss. The smooth surface, being covered closely with minute granulations. The average measurement of eight eggs is $77.7 \times 48.6 \mathrm{~mm}$., and the breeding season given me by this latter contributor is May on Tristan Group, March on Nightingale Island, September on Inaccessible Island ; surely a varied season.

"The flight of the Greater Shearwater is extremely graceful and very characteristic. With long, sharply pointed, slightly decurved wings they scale along close to the waves, sailing into the teeth of the wind by skilfully taking advantage of the air currents deflected upwards from the surges. Now they turn on their side with one wing just grazing the water, the other high in the air. Again they take a few quick wing strokes and land themselves just above a breaker, but so close that one expects to see them overwhelmed in the foam. 
One cannot help noticing the shape of their bodies, cylindrical and tapering posteriorly, a cigar-shape well adapted for rapid passage through the air without 'dragging.'

"Owing to the great length of their wings, Shearwaters need a strong wind to rise from the surface of the water, and even then they often make the surface foam as they climb up the waves paddling vigorously with alternate feet. In perfect calms the advent of a swift-moving steamer in the midst of a flock becomes for these birds a matter of serious concern. They flap along the surface heavily, using both feet and wings, and as they struggle they 'lighten ship ' by vomiting up the contents of their crops and stomachs. Some, unable to rise above the water, endeavour to hide themselves below the surface by vigorous actions of both wings and feet, but in this, as in the case of the proverbial ostrich in the sand, they are only partially successful. Like Petrels, the Shearwaters occasionally skip along the surface of the water on their feet, using their wings to balance and support them.

"The Greater Shearwater is on occasions an active diver, and is able to swim well under water. It dives from the surface of the water on which it first alights.

"Two that had been caught walked as well as ducks and made no pretence of sitting on their rumps. . . . When set at liberty they launched towards the water, dived several yards obliquely, and on coming to the surface splashed and washed themselves for several minutes before they took to wing.

" The vocal performances of the Greater Shearwater are limited to harsh cries and screams which they emit when eager for food.

"The eagerness of these birds for food is so great that they seem to be devoid of all fear of man and recklessly approach close to the boat from which the food supply comes.

"The cylindrical, tapering body, the long curved and pointed wings and graceful flight make the recognition of this Shearwater an easy one. The black bill, white breast and belly, the greyish-brown back and dark head, the white patch at the base of the tail, and the dark bars on the sides and flanks are all points to be noticed in its recognition."

The eggs vary in measurements, the largest being $81 \cdot 7 \times \mathbf{4 7 \cdot 4}$ from Inaccessible Island, September, and the smallest $70 \cdot 3 \times 46.9$; the widest is $80 \cdot 2 \times 52$, Nightingale Island (March), the narrowest $71 \cdot 6 \times 44 \cdot 3$, Inaccessible Island.

It seems unlikely that this bird breeds on the same group in March, May, September and November. Perhaps the islanders who collect these eggs get the dates wrong. I suggest the breeding season as September to November.

[Local name, "Petrel." This is the correct local name among the Tristan people, and not "Pediunker," as has been stated elsewhere, the latter name referring to Adamastor cinereus. About a dozen skins have been sent me at different times, two from Inaccessible being dated 26th April, 1923. The Great Shearwater is plentiful round Tristan, Nicol stating, on the 17th January, 1906, that " it was seen in some abundance, and nearly always two together, so probably breeds there. But it does not appear to nest on this island, though it does so in large numbers on both Inaccessible and Nightingale. The Quest Expedition records that on the 21st May, 1922, " many burrows of this species were found on the hillsides on both islands, but that between 10 a.m. and 5 p.m. very few were occupied. And although many were dug up, there was no trace of a nest, nor did the few birds captured, betrayed by their grunting, show any sign of 
being near the mating period. At night they seemed to flock in by the hundred. The Tristan Group is, curiously enough, the only known breeding place of this common Shearwater, though the eggs in some older collections come from some weird and unlikely places, as Greenland! Seemingly the first authentic eggs were four or five obtained with skins by P. C. Keytel on Inaccessible in November, 1908. (It is stated by Mrs. Barrow, in her book, page 174, that the Rev. J. G. Barrow and a boat's crew from Tristan visited Inaccessible from 5th to 11th November, 1907, and "were able to get a few 'Petrels', eggs, but digging these out of the nest holes was wet and muddy work.")

The first egg I obtained was collected by John Class at Inaccessible on the 11th November, 1917, and was taken from a burrow on a hillside there. It is a small egg measuring only $70 \cdot 3 \times \mathbf{4 6} \cdot 9$. The Rev. H. M. Rogers most kindly sent me a dozen eggs all taken at Inaccessible on the 14th November, 1924. The nests were made of a little dry grass at the end of a long burrow in hillsides, and several of the birds were caught at home. Unfortunately most of these eggs arrived smashed, but $I$ have been able to measure ten which average $77 \times 49$. The 1917 egg is slightly the smallest, while one long pointed egg measures $84.5 \times 50$.

\section{PRIOCELLA ANTARCTICA (Stephens). Silver-grey Petrel.}

This bird was observed on Laurie Island in November and December, and it was considered highly probable that a few pairs were nesting there (Clarke 2). It was said (Clarke 3) to nest at Cape Roquemaurel, on the west coast of Louis Philippe Land.

The maxilla and mandible are tipped with black, the middle portion of the bill pale flesh coloured and the base and nares pale cobalt-blue. Feet pale flesh, the webs washed with yellow, claws black. Iris dark brown and the pupil blueblack. It was recorded by Moseley ; and Wilkins (Ibis, 1923, p. 497) from Tristan.

Lowe and Kinnear (7) say the bird moults in March, and reports it common at sea.

The bird is figured by Gould, vol. vii, pl. 48, 1848, and in Godman's Monograph, pl. 43, 1908, and in my Birds of Austr. vol. ii, pl. 82, 1912.

It breeds at Penguin Point, Haswell Island, and Stillwell Point, Adelie Land, in December [and January ?]. The burrows may be formed in firm snow or in niches among the boulders or ensconced in bowers excavated beneath the snow.

The clutch is one, white, dull and lustreless; oval to pointed oval; the shell is fine grained, with numerous irregularly shaped pittings over the surface. They measure 70,75 and $84 \times 46.5 \mathrm{~mm}$., 48 and 49 . Average of three, $76 \cdot 3$ $47 \cdot 6$ (North).

\section{ADAMASTOR CINEREUS (Gm.). Great Grey Petrel (Pediunker).}

This bird has a vast distribution, breeding on Gough Island in the Atlantic and Round Island near Mauritius and Kerguelen Island; also Macquarie Island, off New Zealand. It occurs around the Antaretic Circle.

This bird was discovered on Cook's voyage, off New Zealand, and beautifully described by Solander as Procellaria pallipes. It is figured by Gould, vol. vii, pl. 47, 1848, Godman's Monogr., pl. 41, 1908, and in my Birds of Austr., vol. ii, pl. 81, 1912 . 
In life from Gough Island the maxilla is dull pea-green ; the nostrils, culmen and unguis are black ; the mandible with apical plate and cutting edge is black, the lower plate pea-green. Tarsus and toes pinkish grey, darker or blackish at the joints, the webs yellowish (Clarke 1).

Lowe and Kinnear (7) give a cut of the bill, showing a different coloured bill for the Austro-New Zealand bird, and say that it dives into the water after the garbage thrown overboard, with its wings half outspread from a position as if it was just about to settle on the water. Wilkins (4) found them in burrows on the hillside about 1,800 ft. up on Gough Island, between May 28th and June 1st, 1922.

The Austro-New Zealand bird differs from the Gough Island form in the colour of its bill. The Austro-New Zealand bird has the tips of both mandibles horn-colour ; the apical plate pale horn-colour, not black; the lower plate dull white, not pea-green. It nests in a burrow on the mountain of Tristan da Cunha in April. The white eggs measure 79-85 $\times 57-58 \mathrm{~mm}$.

[Local name, "Pediunker " or "Paddyunker," which is the correct Tristan name for this species, and does not refer to the Great Shearwater, which is locally known as "Petrel."

In the Appendices to Mrs. Barrow's book the following rather mixed account appears, which from the breeding date, etc., undoubtedly refers to this bird, and not to the Great Shearwater, which nests in November.

" 10 The Pediunker lays in May and June; it is like a Petrel. We think it must be the Shearwater [Priofinus cinereus] of which we were told at the South African Museum, Cape Town, that it frequents Scotland and that its nestingplace was unknown until Mr. Keytel brought a specimen of it and its eggs from Tristan in 1909." I received one skin from Tristan in 1919, and two labelled "Paddyunker," "Inaccessible," 26th April, 1923. Three eggs have also been sent me, one said to be from a burrow with the first skin. One data reads, " 'Paddyunker' eggs from burrows from the side of the mountain, Tristan da Cunha, 6th April, 1923." These eggs measure $85 \times 58,81 \times 53$ and $79 \times 57$. They are dull white, without gloss, the ends being rounded. One is considerably earth-stained. Colonel R. Sparrow has also three Tristan taken eggs which measure $85.2 \times 55,84 \times 56.5$ and $83.5 \times 57.5$, but they are without date. [Are these the eggs of Procellaria? See next species.-G. M. M.]

Although this species has been recorded as breeding at Gough Island, there is, I believe, no record in literature of its occurrence in the Tristan Group. If these are correct, there is something seriously wrong with the eggs recorded previously. Eggs accompanied by a skin of the bird were collected on Macquarie Island in the latter part of November 1896 by Joseph Burton. A. J. Campbell gives the average of seven of these eggs as only $70 \cdot 6 \times 51 \cdot 4$, the largest being $71.5 \times 51.4$, and describes them as either roundish or broad oval; texture of shell close, but coarse, surface very slightly glossy, and colour pure white, but become nest-stained.]

\section{PROCELLARIA AEQUINOCTIALIS AEQUINOCTIALIS (L.). Cape Hen or White-chinned Petrel.}

There is another well-known Petrel to the early travellers. It occurs off the Cape, the Falklands and the Southern Ocean, up to South America and New Zealand. 
Godman figured it in his Monograph, pl. 44, 1908, from Valparaiso-this is brabournei; and I figured the Austro-New Zealand form steadi in my Supplement to the Birds of Norfolk and Lord Howe Islands. The typical form breeds on the Falklands or South Georgia, while mixta breeds on Kerguelen and the Crozets. In my Birds of Australia, vol. ii, p. 111, 1912, I give a text figure of mixta, showing the white extending down the throat, and on p. 112 the very small chin spot of the Austro-New Zealand bird. Gould, in vol. vii, pl. 46, 1848, figured the form known as conspicillata, and so did I, in vol. ii, pl. 79, 1912, of which the type locality is Cape Seas, where the bird I figured was caught at sea by Mr. Richard $\mathrm{H}$. W. Leach, somewhere about 1863 , on his voyage to Australia. In spite of what Gould says, this form does not occur off the Australian-New Zealand waters, and must be removed from the list.

" On Kerguelen they nest in burrows on the sloping sides of a hill, frequently with an inch or two of water at the entrance. The nesting chamber is spherical in shape and rather large ; the nest is composed of mud and pieces of plants arranged in the form of an inverted saucer, three or four inches high, slightly hollowed out on the top, a space being left between its base and the sides of the chamber."

Egg.-Clutch one, white, nearly equally pointed at both ends, and measures $81 \times 52 \mathrm{~mm}$. Breeding season, December.

"Both sexes sit on the egg, the males by day. During the period previous to nesting, the birds make an extraordinary cackling in the burrow at night. When dug out of their nests, if handled the birds utter a high-pitched cry and frequently inflict a severe wound with their beak and claws. They make no attempt to fly, unless chased, but waddle back to their burrows."

On Antipodes Islands the burrows are the same, the egg is laid in December and the young fully hatched in May.

"On Auckland they nest in January and February. Nests consisting of a considerable accumulation of dry grass, placed in an enlarged terminal chamber, at the end of a burrow about three feet long. In the wet peaty bank, the upward sloping burrow opened at its inner end into a chamber about a foot and a half in diameter. The mud from the floor of this chamber had been raked up into a heap in the centre of it, leaving a perfectly formed drain all round, from which the water trickled out down the burrow. The nest was built of grass, as before, and placed in a shallow depression in the central heap, two or three inches above the water in the surrounding drain. I later ascertained that the birds build those heaps by standing knee deep in mud in the middle of the nest chamber and raking the mud inwards with their bills (Stead in Oliver 9).'

Egg.-Clutch one, white and ovoid, $80-83 \times 53.5-55 \mathrm{~mm}$.

Breeding season, December to February. Young fully fledged in May (Oliver 9).

Lowe and Kinnear (7) tell us that when feeding they go completely under water, with their feet and wings outspread, and come up again with the wings still spread, exactly as do the Shearwaters.

[The Quest Expedition in May 1922 saw this species in the vicinity of the group, but the people, when questioned, said that they were seldom seen, and that they did not think they nest at the islands. I have had no skins, nor have the people mentioned it to me.

I have no eggs of this bird myself, and the only description I can find of them 
is that of the Rev. A. E. Eaton, who accompanied the Transit of Venus Expedition to Kerguelen Island.

He describes the breeding season as from November to January, and the nest as a burrow on a sloping hillside with a spherical chamber at the end ; the egg as an elongated oval, coarse in texture, slightly glossy and pure white in colour, measuring $86 \times 52$.

This is much nearer the size and description of the eggs taken on the mountain in April and sent to Col. R. Sparrow and myself, the largest being $85 \times 58$; but the skins are certainly $A$. cinereus, and both skins and eggs are labelled "Paddyunker."]

\section{PTERODROMA MACROPTERA MACROPTERA (Smith). Great-winged Petrel (Black Eaglet).}

This bird breeds on Tristan da Cunha in June and July, not high upon the mountain-side, where it forms a burrow in the ground, at the end of which it lays its egg, oval in shape, white, with no gloss; measurements 68-69 $\times 48-49 \mathrm{~mm}$.

It is figured by Godman in his Monograph, pl. 46, 1908, and I figure the New Zealand form gouldi in vol. ii, pl. 83, 1912, which breeds on the island north of New Zealand; the eggs measuring $65 \cdot 5-67 \times 48 \cdot 5-49 \mathrm{~mm}$. The Western Australian form albani is found on Rabbit Island.

Lowe and Kinnear (7) give a text figure showing the bird in flight.

Dr. R. C. Murphy suggests that "Eaglet" is a corruption of "Haglet," which is a common name for Petrels amongst American whalemen.

[Local name, "Black Eaglet." This is a common Petrel at Tristan, and well known to all the people.

Mrs. Barrow states that it comes in to moult in May, and lays in the first week of July. But she also writes on the 24th May, 1906: "Glass brought back some Eaglets' eggs from the 'Bluff,' they are about as big as a Duck's and white. We had them for supper, they have a slightly fishy taste." On the 13th June she continues: "During a picnic to the 'Base' some 2,000 ft. up my husband looked for Eaglets' eggs, but only found one. The hen was caught but liberated again, when unfortunately the dogs got it." On the 22 nd of that month she adds: "Rob the collie also learned to hunt for Eaglets, which nest in holes, but had to be restrained, as he killed the birds. We had scrambled Eaglets' eggs for breakfast to-day." But from the dates I fear that she must have had scrambled cliffPetrels, as well as their eggs!! She also writes on the 7th October, 1906: "The men, in their spare time just now, hunt for young Eaglets, which they are bringing in in large quantities." The only mention of them in Mrs. Rogers' book is, "Black Eaglets are got in June and July, and we found them good eating."

I have received several Tristan skins, one of which is labelled "Seal Bay, Tristan, 1st June, 1923."

On Tristan they breed plentifully on the hillsides above the "Base," at an elevation of some $2,000 \mathrm{ft}$., making a slight nest in a burrow. The egg is very white and smooth, without gloss, and rather oval in shape. Six eggs average about $68.8 \times 48 \cdot 2$, my largest being $69 \times 49$. They also breed on Inaccessible and Nightingale.] 
PTERODROMA INCERTA (Schlegel). Atlantic Petrel.

This bird was obtained on Tristan da Cunha, and is figured by Godman in his Monograph, pl. 53, 1908, where he considered that it may be a brown phase of lessoni, as it has the blackish mark in front of and round the eye. It is practically the same size.

In my Birds of Australia, vol. ii, p. 148, 1912, I discuss Procellaria alba Gmelin (see also Ibis, 1913, p. 231). However, Loomis, in the Auk, 1920, p. 88, is quite satisfied that alba is the parvirostris of Peale $=$ wortheni of Rothschild, and should be called by the older name.

The Procellaria sandaliata of Solander, the description of which I reproduced on p. 151, is probably this bird, collected off the east coast of South America, at the mouth of the Rio de la Plata. As sandaliata was put as a synonym of arminjoniana in the Catalogue of Birds, vol. $\mathrm{xxv}$, p. 413, 1896, it cannot be again used.

[I do not know of any local name for this Petrel, and only one or two of the people recognize it; though Nicoll states that on the 17th January, 1916, it was observed off Tristan, and possibly nests there also. He describes it as about the size of a large pigeon, dull brown on the back, with almost golden neck, and white underparts. I have only received one skin of this species, from Tristan, and a single egg said to have been taken from a burrow on a hillside at the "Bluff" in June 1918. This egg is dull white, bluntly oval, with a very thin shell, and measures $61.5 \times 48$.] [Is this the first description of the egg of this species?-G. M. M.]

\section{PTERODROMA EXTERNA TRISTANI Mathews. Juan Fernandez Petrel.}

Pterodroma externa tristani Mathews, Bull. B.O.C. lii, p. 63 (1931). Tristan da Cunha.

This bird breeds on the Juan Fernandez Group. It is figured by Godman in his Monograph, pl. 62, 1908; it is replaced in the Kermadec Island Group by the subspecies cervicalis which breeds on Sunday Island. This subspecies is also figured by Godman on pl. 63 ; the Catalogue of Birds, vol. xxv, pl. 6, 1896, and by Buller in his Supplement, pl. iv, 1905. The egg is pure white, broadly ovoid, and measures $64-68 \times 57-48$. The egg is laid at the end of a burrow in December and January, on Sunday Island. In November they are found in their burrows. The young leave the island in June (Oliver 9).

The discovery of this bird on Tristan is most peculiar, as it is a Pacific Island form. Compare ante under Fregettornis grallaria.

In working up the distribution of the Petrels, I find that latitude is most important. That is to say, that the birds in the same latitude resemble each other more closely, although separated by many miles, than do birds separated by many degrees of longitude.

\section{PTERODROMA MOLLIS MOLLIS (Gould). Soft-plumed Petrel (White-breasted Black Eaglet).}

This bird was found breeding on Tristan da Cunha in November of 1917. This is the first time the eggs have been described (see Ibis, 1932, January, p. 165). The bird forms a burrow and lays a single egg at the end, which is enlarged into a chamber. The egg is white, dull with no gloss and measures $63.5 \times 49.8 \mathrm{~mm}$. It is represented by a subspecies feae, which breeds in Madeira and occurs at 
the Desertas and Cape Verde Islands. The Rev. F. C. R. Jourdain writes me that the eggs of this subspecies measure $55.5 \times 41 \cdot 2 ; 52.7 \times 40.2 ; 59 \times 42$; the average being $56.4 \times 41 \cdot 1$; one weighed $2.45 \mathrm{~g}$., another $2.95 \mathrm{~g}$.

The typical form occurs in the South Atlantic and Indian Oceans, east to St. Paul's and Amsterdam Island, and on the west coast of Australia, where three occurrences have been recorded.

It is figured by Gould in vol. vii, pl. 50, 1848, and Godman Monograph, pl. 54, 1908, and I figured a supposed Australia bird, vol. ii, pl. 86, 1912.

The Challenger Expedition obtained two specimens on Nightingale Island on 17th October, 1873, and three examples were secured off Gough Island, and the egg obtained was believed to be of this bird (Clarke 1, p. 262); it measures $61 \times 42 \mathrm{~mm}$. It will be noted that this egg is smaller than the Tristan one and larger than those of feae. The average of the five eggs is $58.2 \times$ $43.04 \mathrm{~mm}$.

Lowe and Kinnear (7) record one taken off Cape Town and one at sea N.W. of Tristan da Cunha, and on pl. vi give a coloured drawing of the head and leg.

Wilkins (4) found them in their burrows in the hillside near the beach on Gough Island, from 28th May to 1st June, 1922. Many others were observed coming inland in the late evening, and their croakings could be heard throughout the night. He also observed them at sea on the voyage from Gough Island to Tristan.

[Local name, White-breasted Black Eaglet. All Mrs. Barrow says of this species is " that it lays in November." However, it seems to be quite well known to the Tristan people, though it was some years before we could make out for what species the above local name stood. However, in 1919 a skin arrived with this local name attached, which proved to be mollis. Unfortunately I have no information as to whether this species is plentiful or not at Tristan, but believe that it is found on all three islands. Two eggs have been received at different times, one taken at Tristan in November 1917 and the other in November 1923. They are dull white with no gloss, rather spherical in shape and measure $64 \times 49 \cdot 6$ and $63.5 \times 49.8$. The nests were at the end of burrows on a slope. Does it also breed at Gough Island ?]

In the Bird Room of the Natural History Museum is a bird of the same size as mollis from South Lat. $36^{\circ} 8^{\prime}$ and East Long. $88^{\circ} 55^{\prime}$. It is uniform dark greyish; the chin and upper throat are mottled, like the lores and forehead. It can be called Pterodroma deceptornis. Type 43-7-14-34. The nearest land is New Amsterdam and St. Paul's Islands.

\section{PTERODROMA BREVIROSTRIS (Less.). Kerguelen Petrel.}

This bird breeds on Kerguelen Island. It is figured by Godman in his Monograph, pl. 60, 1908.

The nest, placed at the end of a burrow of varying lengths, is in an enlarged chamber and composed of damp and decayed vegetable matter. The egg is single, white and measures $50 \times 38 \mathrm{~mm}$. The breeding season is from October to December. Young found in January.

It was recorded from $69^{\circ} 33^{\prime}$ South and $15^{\circ} 19^{\prime}$ West (Clarke 3), and from Australia by Campbell from a specimen washed up in Western Australia on 6th June, 1926. I figured and described it in my Birds of Norfolk and Lord Howe Islands, p. 102, pl. 38, 1928. 
[Local name, "Night-hawk" (?). There is no mention of this Petrel in either Mrs. Barrows' or Mrs. Rogers' books. The people have not mentioned it in any of their lists, but then they have a habit of forgetting species that are quite common there. Nor have I received any skins in any of the collections sent.

The Quest Expedition in May 1922, from questioning the people, include it with a query, as breeding there in November, but they did not see any themselves.

W. B. Alexander, in Birds of the Ocean, 1928, says that it breeds at Tristan da Cunha and Kerguelen. On what authority I do not know.

Among some eggs sent to Col. R. Sparrow from Tristan in 1929 by R. Glass, but with very scanty data, are $A$. cinerea, $P$.gravis, $P$. macroptera, etc., and a single egg which Glass considers distinct, and named " Night-hawk." It is very white, oval and pointed and measures $69.5 \times 53.5$.

I have no eggs of this Petrel myself for comparison.] [Are these the eggs of Adamastor?-G. M. M.]

\section{DAPTION CAPENSIS (L.). Cape Pigeon or Spotted Petrel.}

It is also called the "Pintado " bird, of which the genus name is an anagram.

This widely distributed bird occurs in the Antarctic oceans and northward almost to the equator. It is figured by Gould, vol. vii, pl. 53, 1847; Godman, in his Monograph pl. 80, 1909; and in my Birds of Australia, vol. ii, pl. 90, 1912. The Austro-New Zealand subspecies probably breeds off New Zealand.

The Pintado bird of the world's early navigators is probably the best known of all the Petrels to travellers. Its eggs, however, were not found till 2nd December, 1903, at the South Orkneys (Clarke 2).

"The three nests from which eggs were obtained were placed on open exposed edges of cliffs on the west side of Uruguay Cove, Laurie Island, at heights of from twenty to one hundred feet above sea-level.

"The nests were composed of a few small angular fragments of rocks and a little earth, and contained single eggs, which were quite fresh.

"When approached, the sitting birds ejected an evil-smelling reddish fluid, of semi-digested crustaceans, with great precision for a distance of six or eight feet. They did not, however, leave their nests, and were captured while sitting.

"They seemed of a sociable nature and nested together, but isolated nests were not uncommon. Both sexes were often found sitting side by side, one on the nest and the mate close alongside, and cooing and clucking to each other.

"Eggs were taken also in January. On the 18th of this month a chick five days old was taken, and others were still in down on 5th February.

"The adult, before laying its egg, sits close on the nest for about a month and then entirely disappeared for some ten days, when it returned and laid its egg.

"The eggs, which are pure white, vary from oval to elongate ovate in form. The former measure $56.5 \times 43 \mathrm{~mm}$.; and the latter $67.2 \times 43.3$; the average being $62 \cdot 35$ by $43 \cdot 11$. The length varies from $56 \cdot 5$ to $67 \cdot 2$, and the breadth from $46 \cdot 5$ to $40 \cdot 5$.

"The numerous nests found were placed either on ledges of cliffs, or, though these were few, in hollows in the earth and among small stones on steep screeslopes, and all were quite open. Whereas on Kerguelen they nest in burrows and grottoes. It is also thought to breed at South Georgia. About 20,000 birds of this species nest on Laurie Island. The chick in down, five days old, is slatygrey above, and paler and sooty on the undersurface. 
"A young bird has the head and body clad in down, with feathers developing on the wings and scapulars. The down on the uppersurface is sooty, darker on the head and cheeks, and paler and greyish on the underparts. The wing-quills, the largest of which are two inches in length, are black, some of them with the inner webs white towards the base. The feathers of the scapulars are black and white. There are no signs of tail feathers. Wing eight inches.

" They leave the breeding place in April, and the first of the spring migrants returned on 1st October, and became plentiful by the 23rd."

Further notes were added by Clark (3) ; Lowe and Kinnear (7) do not admit a subspecies, and quote Wilson's note: "I saw one dip entirely, with half-spread wings, to get a piece of garbage, and reappear with a splash like a Shearwater. To rise from the water it had to run on the surface, four or five splashing steps.

\section{PACHYPTILA VITTATA KEYTELI (Mathews). Tristan Broad-billed Prion (Nightbird).}

This bird lays its eggs on the stones at the back of a dark cave on Inaccessible Island in September (10th, 1917) (cf. Ibis, 1932, January, p. 165).

It is recorded for Gough Island (Clarke 1) with a wing of $220 \mathrm{~mm}$. The lower plate of the mandible was pale blue and the remainder of the bill black; tarsus and toes cobalt-blue, webs black. Wilkins (4) says it lays in September. He also dug them out of deep burrows on the hillside near the beach on Gough Island between 28th May and 1st June.

[Local name, "Nightbird." This species, once common, seems to have become scarce at Tristan. Mrs. Barrow writes, 17th September, 1908: "Mr. Keytel, my husband and Rapetto went by boat to visit Freshwater Cave in search of Nightbirds. The cave is about 100 yards in length. At the far end is a pebbly beach where the birds were supposed to be. Between it and the mouth was water which had to be crossed. They saw about a dozen Nightbirds and got seven eggs." Mrs. Rogers also visited this cave in 1923, and writes : "There is a shingly beach, and a small dark cave at the end at one time the haunt of Nightbirds, but they seem now to have completely deserted it. Indeed, these birds seem to be leaving Tristan now. They used to be easily caught by the curious expedient of lighting fires in the eaves, which attracted them down. Their eggs are very good eating. Near by is 'Guano' or 'Dry' Cave, also about 100 yards long and fairly lofty. The floor is of sand mixed with guano, and quite dry. But the birds have now deserted it also." However, they still breed in some numbers on both Inaccessible and Nightingale. One skin was received from Tristan in 1919, and two obtained at Inaccessible on the 26th April, 1923. I have only two eggs, white and smooth and rather oval in shape. One taken at Freshwater Cave on the 10th September, 1917, measures $52.5 \times 35$, and the other at the same place on the 20 th September, 1922 , is $51.5 \times 35$.]

\section{MACRONECTES GIGANTEUS (Gmel.). Giant Petrel.}

This large dimorphic, ugly-billed Petrel, the Nelly of sailors, has a bad reputation, as it catches and swallows whole, the Prion, on the wing.

It is figured by Gould, vol. vii, pl. 45, 1848; Godman, in his Monograph, pl. 76, 1909; and in my Birds of Austr. vol. ii, pl. 89, 1912.

If we consider giganteus to be the Staaten Land form, including the South 
Orkneys, and breeding on Graham's Land; and treat the Falkland Island form (solanderi) and the Kerguelen Island breeding bird (halli) as wandering in the off season up the western coast of South America (forsteri), as synonyms, we must admit the Austro-New Zealand subspecies albus, with the Ross Sea bird (wilsoni) and the Australian form (dovei), as synonyms.

This makes the Tristan breeding bird also giganteus, which seems wrong; perhaps solanderi would be more correct.

This bird breeds on Gough Island (Clarke 1), where it lays its egg in the middle of September. It enters the Penguin rookeries and carries off the young; and it pulls Petrels out of their holes. The egg is ovoid to elliptical, white, shell coarse and granulated and rough with no indication of gloss.

"Breeding season, South Georgia, November, December and January; Falkland Islands, October and November; Gough Island, September.

" Five thousand birds nest on Laurie Island, South Orkney Islands (Clarke 2). They nest in rookeries, and the nests consist of great piles of small angular stones and measure two feet in diameter. The clutch is single, and the average (80 eggs) is $103 \cdot 8 \times 65 \cdot 7 . \mathrm{mm}$.

"The bird had to be pushed off the nest to get the egg. They showed no fight, and usually sat down a yard away. They did not shoot oil from their nostrils, but vomited the contents of their stomachs, not as defence, but to lighten themselves before taking to the wing."

A photo appears of nest, egg and adult on pl. xi.

Lowe and Kinnear (7) devote twelve pages to this bird, of which four and a half are measurements of tarsus and the length and depth of the bills. In all about a hundred birds are measured. They admit no subspecies, although two are indicated. They prove that the white phase starts life in white down and the dark phase in dark down. That is, age had nothing to do with colour; this I have always thought to be the case. Young Diomedia exulans can always be distinguished from Macronectes by the fact that exulans at all ages has the underwing white, with a black tip and edging, whereas all dark phases of Macronectes have the underwing dark. Otherwise both are very dark on the upperparts and show no white.

[It is stated in Sclater, Syst. Av. Aethiop. i, p. 15, 1924, that it breeds at Tristan. Alexander, in Birds of the Ocean, 1828, repeats this. However, no skins, or eggs, have been sent me by the people as yet, nor has it been mentioned in any of their letters, and it seems strange that, if these large, conspicuous birds breed at all commonly at the islands, no one seems to know it.

It breeds commonly at Gough Island, some 250 miles away. Two eggs of the $M . g$. solanderi, which is said to be the subspecies occurring in these seas, from the Falkland Islands measure $102 \cdot 3 \times 63$ and $101 \times 65 \cdot 2$, and are very white and rough in texture; while two eggs of the typical race from South Georgia are $106 \times 65$ and $100 \times 66$.

The nest is just a hollow on the ground.]

\section{PELECANOIDES URINATRIX DACUNHAE Nicoll. Tristan Diving Petrel (Flying Penguin).}

This form breeds on Tristan; the Austro-New Zealand bird is figured by Gould, vol. vii, pl. 60, 1844 ; Godman figured a form in his Monograph, pl. 86, 
1910, and the Kerguelen bird exsul, pl. 87 ; and I figured the Chatham Island subspecies, vol. ii, pl. 94, 1912. There are about half a dozen forms.

It is recorded from Gough Island (Clarke 1). It breeds on Nightingale Island in November; the clutch is single, white, dull with no gloss, and oval in shape. $36.5 \times 30 \mathrm{~mm}$. ; $38 \times 29$. The egg is placed at the end of a burrow.

[Local name, "Flying Penguin." This Diving Petrel is peculiar to the Tristan group, and was first recognized by Nicoll on the 17th January, 1906, off Tristan, who remarks: "a new species, half a mile from the shore they were on all sides." However, since that date very little seems to have been recorded about this bird, and neither Mrs. Barrow nor Mrs. Rogers mention it in their books. No skins have been found in any of the collections received, nor have any of the natives mentioned it in their lists or notes of species found in the islands.

Among the last eggs given me by the Rev. H. M. Rogers is one supposed to be that of this little Petrel. It is white, rather stained, and roundish in shape, and measures $38 \times 29$. It was taken from a small burrow lined with feathers, etc., at Inaccessible on the 14th November, 1924.

In January 1930 Colonel R. Sparrow, who had obtained some eggs from Tristan (mostly broken), most generously gave me an egg of this bird taken by R. Glass at Nightingale in 1929. Unfortunately his data is very vague. All he says is, "No. 5 The Flying Penguin, one of the most important birds which lay on Nightingale Island, which I went especially across with my boat for to collect Seabirds' shells." This egg measures $36.5 \times 30$, and is much like the other but rather rounder and more stained.]

\section{DIOMEDEA EXULANS EXULANS L. Wandering Albatross (Gony).}

This bird formerly bred on Tristan da Cunha, now only on Inaccessible Island in this group. Gould figured it in vol. vii, pl. 38, 1844 ; and Godman, pl. 89, 1910 ; and I figured the Austro-New Zealand form in vol. ii, 95, 1912.

It also breeds on Gough Island (Clarke 1) in December (end) and January. The young stay on the island till they are ten months old before they go to sea. Numbers are killed by the Nellies and Skuas, only about 5 per cent. reach maturity.

Lowe and Kinnear (7) give a text figure showing a scarlet mark on the head behind the eyes, like a red collar. They give the plumage changes from nestling, through four changes, to adult, and consider chionoptera to be the Kerguelen Island subspecies.

[Local name, "Gony." Mrs. Barrow writes, 9th February, 1907: " Yesterday the men went out in a boat to shoot Albatrosses, and got seven. Once they nested on the island, but now nests are not to be found nearer than Inaccessible Island." Mrs. Rogers also remarks in 1923: "Albatrosses have entirely left the island."

Four skins were received in 1919 from John Glass and Tom Rogers, but an egg they also sent, with others, never arrived !

However, the Rev. H. M. Rogers sent me a single egg taken on Inaccessible Island on the 1st November, 1924, with the remarks: "Nest cone-shaped, and over a foot high, among grass. Only a few breed here now." This egg, considerably stained and seemingly unmarked, measures $134 \times 76 \mathrm{~mm}$. How it 
arrived here unbroken is a marvel, as it was half out of the box when I received it from the postman!!]

\section{THALASSARCHE MELANOPHRIS MELANOPHRIS (Temm.). Black-browed Mollymawk.}

This bird is found off South Africa and the Atlantic and Indian Oceans ; breeding at the Falkland and Kerguelen Islands. It includes belcheri from Kerguelen and richmondi from the west of South America as synonyms, and is replaced by impavida from the Australian waters.

It is figured by Gould, vol. vii, pl. 43, 1844; and Godman, pl. 97, 1910; and I figured the Australian form in vol. ii, pl. 96, 1912.

This bird was not found on Gough Island (Clarke 1), but was collected on Tristan. Lowe and Kinnear (7) give a coloured figure of the head, and say that this bird settles on the water when things are thrown overboard, and then from that position dives completely under after them if necessary. It dives into and under water with three-quarters expanded wings, coming up with the wings still half open. After examining and measuring a long series, they admit two subspecies as above. It appears not to breed on Tristan.

[This species does not seem to have been recorded by any writer from the Tristan group, nor is it recognized by the inhabitants. But there is a single skin in the collection sent me by John Glass and Tom Rogers in 1919 which seems to be the first obtained there. However, the Quest Expedition state that it was seen at Gough Island, and also at the Tristan group in May 1922. So that it is not unlikely that it breeds unobserved on one of the islands.

Eggs of the typical form from the Falkland Islands, where it breeds plentifully, are rather narrow as a rule, the spots and blotches being more liver-coloured than red. Eight eggs average $105 \times 66 \mathrm{~mm}$.

It is interesting to note that the eggs of these three species can be separated in a series with fair certainty. Those of $T$. chlororhynchus being the smallest, while $P . f$.fusca eggs are much wider, and those of $T$. melanophris average considerably longer.]

\section{THALASSARCHE CHLORORHYNCHUS CHLORORHYNCHUS (Gm.). Yellow- nosed Mollymawk (Mollyhawk).}

From the Cape all over the Southern Ocean, this bird is seen at some season of the year. It breeds on the Tristan Group, probably Nightingale Island, where it was found resting (Wilkins 4 ) on the grass in an open glade near the summit of that island. It was quite tame and allowed itself to be caught.

It is figured by Gould in vol. vii, pl. 42, 1844; by Godman, pl. 102, 1910; and by myself in vol. ii., pl. 98, 1912. The form carteri was also figured by Godman, pl. 102A, and myself, pl. 99. Lowe and Kinnear (7) consider that there are only two forms of this bird, and put eximius from Gough Island, and carteri, an accidental visitor to west coast of Australia, as synonyms. The Australian subspecies they call bassi, and give the reason for their decision.

Australia.-Adult: head, entire neck and underparts pure white ; mantle greyish brown; ocular streak and loral smudge faint. When freshly moulted a slight tinge of bluish grey suffuses the sides of the head, nape and hind neck.

Tristan da Cunha.-Top of head white; sides of face, nape and hind neck 
very distinctly washed with grey ; chin, throat and underparts white; mantle greyish brown ; ocular streak and loral smudge of a darker and more decided tone.

Moseley, writing of this Mollymawk (chlororhynchus) from Nightingale Island, says that it is about the size of a goose, the bill is black with a yellow streak on the top and with a bright yellow edge to the gape, which extends right back under the eye. Carmichael says that when irritated the feathers of its cheeks are separated, so as to display a beautiful stripe of naked orange skin, running from the corners of the mouth towards the back of the head, which is a continuation of the gape.

It seems strange that well over a century has passed and still we have no drawing showing this yellow line.

"The birds make a cylindrical nest of tufts of grass, clay and sedge, which stand up from the ground. The nest is neat and round. There is a shallow concavity on the top for the bird to sit in, and the edge overhangs somewhat, the old bird undermining it during incubation by pecking away the turf of which it is made. The nest is fourteen inches in diameter and ten inches high. The bird lays a single egg, elongate, with one end larger than the other, as are all albatross eggs.

"The egg is held in a sort of pouch, whilst the bird is incubating. Thus the bird has to be driven right off the nest before it will drop the egg out of its pouch.

" The birds, when approached, sit quietly on their nest or stand by them and never attempt to fly; indeed, they seem, when thus bent on nesting, to have almost forgotten the use of their wings.

"When bullied with a stick or handled on the nests, the birds snap their bills rapidly together with a defiant air, but they may be pushed or poked off with great ease. Usually a pair is to be seen at each nest, and then by standing near a short time one may see a curious courtship going on.

"The male stretches his neck out, erects his wings and feathers a bit, and utters a series of high-pitched, rapidly repeated sounds, not unlike a shrill laugh; as he does this he puts his head close up against that of the female.

"Then the female stretches her neck straight up and, turning up her beak, utters a similar sound, and rubs bills with the male again. The same manœuvre is constantly repeated.

"Sometimes they nest right in the middle of a penguin road, or they take up their abode in separate pairs anywhere in the rookery, or under the trees where there are no penguins, which latter situation they seem to prefer."

[Local names, "Mollyhawk" or "Mollymawk." This appears to be the common Albatross in the group, and occurs in large numbers on all three islands ; and although Mrs. Rogers states that the flesh is very strong and unpleasant, many are eaten by the people. They are hunted from January to March, and in 1923, while 2,139 were taken in January, no less than 4,800 were killed in March. The Rev. H. M. Rogers tried to keep statistics of the various birds' eggs taken for food, etc., during his stay.

They come to nest in August, lay during October, and leave again in April. The eggs are also used in large numbers for food, and on the 7th October, 1906, Mrs. Barrow writes: "Mollyhawk eggs are just in, and nearly every man has been out on the mountain after eggs. John Glass got 162. The men say that this bird never lays more than one egg each season. In time I fear that these beautiful birds will be driven from the island." 
On the 6th February, 1907, she also says : "While sitting on the cliffs at Sandy Point, a pair perched within a few feet of us. They are exceedingly handsome birds, for the most part white, their bills black, with a bright yellow stripe down the middle. They have the most graceful movements, and this pair bowed, and clicked their bills together, and made love to each other in the most charming way. They cannot rise off flat ground unless there is wind, only from a hill or cliff edge. On the 5th January near the ponds among bushes and fern," she continues, "we came across a good many Mollyhawks sitting on their nests, which they seem to frequent after the young ones have flown. We also saw 1 or 2 of the young, which are covered with a fluffy blue down. While on the 24th of April, also near the ponds, we saw many young ones, sitting near their nests, and looking white in the undergrowth." There are several large breeding colonies on Tristan, the nests being cones of peat, etc., placed among the bushes and fern, specially near the ponds and above the base.

The single egg is more or less dusted and freckled, or ringed with reddish spots at one end. Twenty eggs average $96.5 \times 62.5$.

They also breed at Inaccessible. While at Nightingale Island the Rev. H. M. Rogers wrote, on the 31st January, 1924: "The Mollymawks thrive here, both in the tussac and in the open valleys, as well as on the cliffs. I saw one rookery in a beautiful but swampy valley, containing over 500 of these handsome birds, right in the middle of the island."

Three skins have been sent me from Tristan.]

\section{[THALASSARCHE CHRYSOSTOMA Forster. Grey-headed Mollymawk.}

The eggs of this bird were found on South Georgia (Wilkins 4) for the first time. Not recorded from the Tristan Group.

Young.-Just hatched. Light grey down, slightly darker on the wings, becoming darker with age. Bill dark horn-colour ; iris light brown ; feet light grey.

Nest.-Cone-shaped, twelve to fourteen inches high; about a foot wide at the top and about twenty inches at the bottom, with moss and earth, lined with grass.

The nests are used each year for breeding purposes. The young birds have to be pushed off, in order that the parents may lay a new season's egg.

Egg.-Clutch one, dull white ; average measurements $101 \times 74 \mathrm{~mm}$.

Breeding Season.-December and January, South Georgia. Young hatched on January 1st.]

Although this form does not occur on the Tristan Group, it is included for comparison.

\section{PHOEBETRIA FUSCA FUSCA (Hils.). Sooty Albatross (Pe-o).}

This species and the former (chlororhynchus) were described as nesting on Tristan as far back as 1818. The bird is figured by Gould, vol. vii, pl. 44, 1848; Godman, pl. 103, 1910; and I figured it in my Birds of Norfolk and Lord Howe Islands, pl. 41, 1928.

It is reported as breeding on Gough Island (Clarke 1), bill " dark, with a yellow stripe on each side." It is common, but does not breed in rookeries ; it places its nests separately on cliffs or projecting rocks, where it is most difficult 
to get at them. The bird commences to lay by the middle of September, and while sitting keeps up a continual cry similar to that of a young goat. This is the only Sooty Albatross seen at Tristan (Wilkins 4), although a watch was specially kept for palpebrata. Lowe and Kinnear (7) give a coloured figure of the head of palpebrata. In the A.O.U. Check List, 1931, p. 366, auduboni is considered a South Pacific Ocean bird, and therefore becomes a synonym of $P$. palpebrata huttoni.

[Local name, "Pe-o " or "Pe-ho." Common on Tristan, though not nearly so numerous as $T$. chlororhynchus. It comes in to nest in August and leaves again in April. This species, which is well known to the natives, is described as a "brown bird with yellow on the bill."

I received two Tristan skins in 1819.

They breed on the island during October in some numbers, but not in large colonies in the grass and fern like the "Mollyhawk," the cone-shaped nest being usually placed in dangerous situations on the edge of cliffs on the coast or inside the crater on the mountain.

Curiously enough, I have no records from either Inaccessible or Nightingale, though they probably occur there too.

Eggs vary in shape and size, some being almost unmarked, while others are spotted, ringed or speckled with reddish.

Eight eggs average $100 \times 67$.]

\section{ATLANTISIA ROGERSI Lowe. Tristan Rail (Island Cock).}

We owe the discovery of this bird to the Rev. H. M. C. Rogers, acting ResidentChaplain on Tristan da Cunha, who forwarded two skins to the British Museum in 1923. Later he forwarded the body of a bird in spirits.

Dr. P. R. Lowe described it as a new genus and species, and later (Ibis, 1928) gave an exhaustive monograph, with a coloured figure. He says that it is the smallest flightless bird known to exist, or to have existed. It is said to live in burrow, under the talus slopes on Inaccessible Island, and to be a fast runner.

In the Bulletin of the British Ornithologists' Club, vol. xlviii, p. 121, July 10th, 1928, Lord Rothschild described the eggs.

Clutch three (?); greyish milk-white tinged with buff; dotted all over sparingly with rather small chocolate-rufous spots and underlying ones of lavender-mauve; all markings are considerably more concentrated round the apex. The measurements are $35 \times 25 \mathrm{~mm}$.

The eggs are typical Rail's eggs and very large for the size of the bird, and almost indistinguishable from some varieties of the eggs of Crex crex.

Breeding season, October and November.

Mrs. Rogers (12) says that it can run with great speed, shelters in the tussocks and lives in a burrow.

This bird occurs only on Inaccessible Island, where Mr. Philip Lindsay discovered the nest in 1927 and 1928 .

[Local name, "Island Cock."

On the 2nd February, 1923, the Rev. Rogers visited Inaccessible with three boats' crews and succeeded in obtaining two specimens, now in the British Museum. He described this Rail as unable to fly, but runs with great speed, and shelters in the tussac. It lives in a burrow, and feeds on insects and worms. 
Tom Rogers sent me a single skin, now in the Royal Scottish Museum, labelled “' Island Cock,' Inaccessible Island, 5th May, 1923. They are the hardest little birds to catch.']

\section{PORPHYRIORNIS NESIOTIS NESIOTIS (Scl.). Tristan Coot.}

This bird is figured at the original description; and notes on the Gough Island subspecies are quoted in the Ibis (Clarke 1) under the name P. comeri Allen. The two forms are very similar.

\section{LARUS DOMINICANUS DOMINICANUS Licht. Southern Black-backed Gull.}

This bird ranges from South Africa to Kerguelen; South America and the Southern Ocean ; Tristan, Gough Island, etc., and is represented in New Zealand by a subspecies antipodus, which is figured by Buller in his first edition, pl. 20 . The typical form is figured in Gray and Mitchell's Genera of Birds, vol. iii, pl. $180,1845$.

It is not recorded from Gough Island (Clarke 1), but breeds on Laurie Island, South Orkney Island (Clarke 2), where some remain all the year round, the return of the spring immigrants commencing in mid-October. The birds were paired on 3rd November and the first eggs laid on the 15th. The first young mentioned, 19th December. Fresh eggs marked on 3rd December were found chipped on the 28th, an incubation period of about twenty-five days. Young in down as late as 30th January.

"The nests were placed on raised beaches, small screes and rocks within a few yards of the shore. The nest was a well-built structure of seaweeds, mosses, lichens and feathers, and was usually surrounded by great quantities of limpetshells, this mollusk being evidently a favourite food of the bird. The eggs were usually two in number, but sometimes three and occasionally only one. Wilkins (4) did not consider that they nested on Nightingale Island, although he procured an immature male there on 21st May, 1922."

The New Zealand eggs (clutch two or three) vary from green to stone and dark stone, with large dark and pale-brown blotches, chiefly at the larger end, and measure $69-72 \times 47-50 \mathrm{~mm}$. It breeds in scattered colonies on shingly river beds and coastal rocks and beaches. The nest is sometimes a mere hollow in the sand, with a few pieces of grass or sedge as lining; at others they are large and made entirely of leaves. The upper portion of the nest is composed of dry leaves ; the base consists of more or less decomposed leaves and earth-apparently the birds forming a new nest on the old one of the year before. November is the usual laying month and three the most common number of eggs (Oliver 9).

[Surprisingly little seems to be known in Tristan regarding the status of this species, and I have only received a single immature skin in the collections sent.

However, the Quest Expedition, on the 21st May, 1922, saw many immature birds at Nightingale Island, and obtained one, a juvenile male of the year, which they thought must have been bred on the island, as it seemed much too young to have travelled any great distance. But no adults were seen, and the natives, when questioned, did not think that any bred in the group, although adults were sometimes observed. This species is very destructive to eggs and young of other birds, and will also attack a weakly lamb. I have no Tristan eggs, but in Appendix II in Mrs. Rogers' book, in the list of Natural History specimens 
collected by them at Tristan, and now in the British Museum, appears No. 6 egg of the Southern Black-backed Gull (Larus dominicanus), but I fear some mistake.

The nest is placed on a rock, or near the shore, and is composed of dry grass, or seaweed. Two or three eggs are laid, generally stone-colour spotted with brown and black. This species has a very wide breeding range. C/2 from Cape Colony measure $75 \times 48$ and $72 \times 49$. A c/3 from Buenos Aires are $74.5 \times 50$, $70 \times 49.5,60 \times 52 . \quad \mathrm{C} / 2$ from Megellanes measure $70.5 \times 52$ and $69.5 \times 50$. A c $/ 3$ Falkland Isles are $73 \times 51 \cdot 5,73 \times 52,74 \times 51$. But a c/2 Larus d. antipodus from New Zealand are very dark narrow eggs and measure $72 \times 47$ and $70 \times 47$.

\section{CATHARACTA ANTARCTICA ANTARCTICA (Less.). Antarctic Skua (Sea-hen).}

This hawk amongst gulls frequents the southern area, breeding on the Falkland Islands ; it occurs at Gough Island and Tristan, and has wandered to Australia. The Indian Ocean form, intercedens, breeds in Kerguelen; clarkei occurs in the South Orkneys, South Shetlands and South Georgia ; lonnbergi is the Austro-New Zealand bird ; and maccormicki is from Antarctica, breeding at Victoria Land.

I have figured the Austro-New Zealand form in my Birds of Australia, vol. ii, p. 122, 1913, and maccormicki in my Birds of Norfolk and Lord Howe Islands, pl. 42, 1928, and the Australian example of the typical bird in the Supplement not yet published. On Gough Island they commence to lay in the middle of September (Clarke 1): when the Penguins lay, the Sea-hens come ashore in large numbers and get their living by robbing the nests and catching the young. They also kill the young albatrosses. They nest on Laurie Island, South Orkney Islands (Clarke 2). They leave during the winter months after 28th April and return on 16th October. The first eggs were laid on 2nd December and young were out by 22nd January. By 11th February dark feathers were appearing on the wings and sides of the breast of those youngsters. Incubation period about six weeks ; next year, 1904, they returned on 21 st October, and the first eggs were found on 27th November.

"The nests were usually placed on the tops of mossy rocks, or on plateaux from 100 to 400 feet above the sea, and consisted of well-made hollows in the moss, while teased-out fragments of moss formed the lining. Occasionally nests were found on the tops of moraines and were then hollows in the earth lined with lichens.

" The eggs were two in number, on which the bird sat very close, her mate usually remaining near at hand. When approached, the owners screamed defiance and the sitting bird had to be forcibly ejected from the nest. The nests were surrounded by many shells of eggs and remains of young penguins. The young soon wandered from the nest and were most difficult to detect among the moss. Wilkins (4) said that they were seen in great numbers about each island of the Tristan group."

Lowe and Kinnear (7) have published eleven pages on this bird, five of which deal with measurements; they make all forms subspecies of Catharacta skua and admit seven forms. They go carefully into the plumages, from the cinnamonred to the straw or lighter-coloured feathers.

[Local name, "Sea hen." This well-known species is resident and plentiful on all three islands. They are great robbers and devour the eggs and young of 
other species, and Mrs. Barrow has seen them attack and kill a weakly lamb more than once.

I have received four or five skins, one of which is dated 17th April, 1923. Antaretic Skuas breed during August and September, singly as a rule, and the nests are just scrapes lined with a little grass or weed, and placed near the shore. Two eggs are laid, showing considerable variation, even in a clutch, being pale olive, greenish, or dark brownish, more or less spotted with dark brown at the larger end, and rather dumpy in shape. Ten eggs are very uniform in size and average $70 \times 51$, while four eggs from the Falkland Islands average $69.5 \times 49$, being slightly shorter and distinctly narrower. For comparison, 100 eggs of the British bird average $70.59 \times 49 \cdot 37$.]

\section{STERNA VITTATA VITTATA Gmel. Sub-Antarctic Tern (Kingbird).}

This bird occurs in the South Atlantic and Indian Ocean and off South Africa ; it breeds on St. Paul's Island and Tristan da Cunha, and is represented in New Zealand by the subspecies bethunei. The typical form is from Christmas Harbour, Kerguelen. I have figured it in the Supplement to my Birds of Norfolk and Lord Howe Islands. It occurs in Gough Island (Clarke 1 and Wilkins 4).

[Local name, "Kingbird." Of this species Nicol writes, 17th January, 1906, "Very like our common Tern, and judging from the numbers of young just able to fly, there must be a considerable nesting colony." While all that Mrs. Barrow says about them is : "Comes in September, and lays in November." I have received several skins, two of which, one adult and the other immature, were shot at Tristan on the 15th February, 1923. All my eggs come from Sandy Point, on the east side of the island, but they may breed elsewhere. One or two eggs are laid on the bare sandy ground, with a few straws at times for lining. Six eggs taken on the 14th November, 1923, and 16th November, 1924, average $46 \times 32 \mathrm{~mm}$., the largest being $47.5 \times 33$. Four are stone colour with small grey, brown and blackish spots, mostly at the larger end, while two are much darker and more heavily spotted.]

\section{ANOUS STOLIDUS STOLIDUS (L.). Noddy (Wood Pigeon).}

This Tern is distributed throughout the tropical seas, in the Atlantic Ocean breeding at St. Helena, Ascension and Tristan; off Africa from the Gold Coast to the Congo. The Indian Ocean has the subspecies, rousseaui, from Madagascar ; plumbeigularis occurs in the Red Sea ; pileatus is from the Philippines, Liu Kiu Islands and China; unicolor from the South Pacific; galapagensis from the Galapagos Islands ; ridgwayi from the west coast of Mexico ; and the Australian bird is gilberti, of which antelius is a synonym. Gould figured it in vol. vii, pl. 34, 1846, and I in vol. ii, pl. 115, 1912. It occurs on Gough Island (Clarke 1) and nests at Tristan.

[Local name, "Wood Pigeon." Comes in September, lays in November, but goes away for the winter. This species seems rather scarce at Tristan, although I have received one or two skins. On the 14th November, $1907 \mathrm{Mrs}$. Barrow writes: "My husband and Rapetto went off to the 'Hardies,' some rocks, in the sea, beyond 'Hottentot Point,' in search of 'Wood Pigeons,' eggs. This is a seabird, in spite of its land-sounding name. They had to swim to a high rock a short distance from the shore, and then climb to the top of it. It was 
rather too early for eggs, and they only found one, but satisfied themselves of its identity. These rocks, the 'Hardies,' are the only actual nesting-places that I know of, though there are probably others, and only a few breed there." These eggs, taken on the 24th November, 1923, and 20th November, 1924, at these rocks measure $51 \times 35,49 \times 36$ and $48 \times 34$; two are slightly spotted with grey and reddish brown, while the middle one is almost unmarked.

The Rev. H. M. Rogers reported large numbers on Nightingale Island on the 31st January, 1924, and remarks : The 'Wood Pigeon' is a big bird, black and grey, with a long beak, and utters a rather cawing note.']

\section{MEGALOPTERUS MINUTUS ATLANTICUS Mathews. White-capped Noddy.}

This form occurs in the Atlantic, breeding on Ascension Island, St. Helena and Inaccessible Island. The Australian form is minutus and the Philippine one is worcesteri; Marcus Island has marcusi; while from Cocus to Clippeaton diamesus occurs ; and americanus is from the Caribbean Sea.

Gould figured it in vol. vii, pl. 36, 1846, and I in vol. ii, p. 117, 1912.

[It is stated in the Syst. Av. Aethiop. i, p. 155, 1924, that it occurs on Inaccessible Island of the Tristan group.

No skins have been sent me, nor have I any record of it, but I do not think that the Islanders can distinguish between these two rather similar Noddies, even though their nests are so unlike. Mr. Rogers does not mention any Noddy at Inaccessible, though on the 31 st January, 1924, here marks on the large numbers seen at Nightingale Island.

The nest is composed of fresh seaweed slightly hollowed and firmly cemented to the branch of a tree or side of a rock.

The egg is whitish stone with a few grey dots, the larger end being spotted with reddish brown. It measures $45-47 \times 31 \cdot 5-33$.

I have one very small Noddy egg, only $47.9 \times 34$, with a few grey and brownish dots at the top, taken 18th November, 1917, in the group.]

\section{NESOCICHLA EREMITA EREMITA Gould. Tristan Thrush (Starchy). NESOCICHLA EREMITA GORDONI Stenh. Inaccessible Island Thrush.}

The typical form is confined to Tristan and is said to be extinct; a subspecies occurs on Inaccessible and Nightingale Islands. In the Challenger Report, p. iii, we are told that seven skins were collected on Tristan, and the coloured figure on pl. xxiii was made for the first time. A cut of the leg, wing and bill from the above is also given. The subspecies gordoni was collected on Inaccessible as told by Stenhouse. The sexes are alike. They are found in all parts of each island (Wilkins 4). They seemed to prefer the more open glades, where the tussock grass grows rankly. More often than not they perched on the branches of trees when disturbed in feeding on the flies and insects found by the edge of streams and near the beach. They were not seen on Gough Island.

In Cat. Birds Brit. Mus. vi, p. 332, 1881, Sharpe considered this a true Thrush, which Seebohm had not admitted in vol. v., p. 404, 1881. In Ibis for 1923, pp. 523-9, Dr. P. R. Lowe has given us a detailed account of the structure, and gives a text-figure of the peculiar tongue, the sternum and a front and back 
view of the pterylosis. And on pp. 528-9 gives measurements of the wing, bill and tarsus of examples from the three islands in the group. The Tristan bird is smaller in the wing, and is paler and more fulvous than those from the other two islands, which are similar to each other (gordoni).

[Local name, "Starchy." On the 10th August, 1907, Mrs. Barrow writes "William to-day brought in a bird which he calls a 'Starchy,' but which is just like our old friend the garden thrush. He says that there are lots on the hill. They have no song." In Mrs. Rogers' book there is no mention of it at Tristan. When the Quest called there in May 1922, it was reported to be extinct. So that the two Tristan specimens I received in 1919, and now in the Royal Scottish Museum, are probably among the last of their race. No eggs seem to be known from Tristan.

In 1924 the late Surg.-Admiral J. H. Stenhouse separated this race from the Tristan form on the strength of larger size, darker plumage, and especially the larger, deeper bill. The three skins sent were collected at Inaccessible on the 26 th April, 1923, where the bird is still plentiful ; it also occurs at Nightingale. Eggs, though described to the Challenger Expedition in 1873 by the Stoltenhoff brothers, were unknown until 1923, when the Rev. H. M. Rogers discovered two nests on the 3rd February at Inaccessible. The nests were cup-shaped, of various dry grasses, etc., one in tussac and the other in an " island tree." The eggs are blue with rusty spots and freckles. Both nests contained two eggs, No. 1 measuring $29 \times 23$ and $29 \times 22$, while No. 2 is $31 \times 21$ and $29 \times 22$, one egg being rather elongated.]

\section{NESOSPIZA ACUNHAE ACUNHAE Cab. Tristan Bunting (Canary). NESOSPIZA ACUNHAE QUESTI Lowe. Nightingale Island Bunting.}

The first occurred only on Tristan, where it is believed to be extinct and the latter still lives on Nightingale Island.

The typical form is figured in the Challenger Report, pl. xxiv, from Inaccessible, and on p. 112 a cut of the foot, wing and side view of the head is given.

This bird was described in 1873 by Cabanis from an old skin acquired by the Berlin Museum, from the sale of the Bullock collection.

This bird "builds in the bushes, and lays four or five eggs very like those of the Common Canary." Wilkins (4) says that the birds are very tame and are found in considerable numbers in all parts of the two islands, Nightingale and Inaccessible. On the beaches and the uplands they were feeding on the flies and insects found in damp places ; also on the seeds of tussocks grass. Lowe (5), working up this material, p. 519, gives an account of the bird, and on p. 520 described a new subspecies from Nightingale, and on p. 521 gives measurements of the Inaccessible and Nightingale Island birds, showing the smaller size of the latter ; on p. 522 is a text-figure of the head and wing of this and wilkinsi.

The bird described by Cabanis at the same time as the above, that is Crithagra insularis, in the Journ. f. Ornith. 1873, p. 153, as supposed also to be from Tristan, has been a stumbling-block to many. However, Dr. E. Stresemann, who has examined the type, tells me that it is a synonym of Serinus flaviventris (Swainson 1828) from South Africa, and the locality guessed (ef. Ornith. Monatsber. 1923, p. 142). Crithagra of Swainson, in Cat. Birds Brit. Mus. xii, p. 348, 1888, is placed as a synonym of Serinus, but it may be a good genus. 


\section{NESOSPIZA WILKINSI Lowe. Nightingale Island Large Bunting.}

This new species from Nightingale Island is a giant of the former bird. It has the same colouring as the others (questi), but is a much bigger and heavier bird in every way (Wilkins 4). Lowe, in the Ibis for 1923, p. 521, described it as a new species; the drawing of the head and wing on p. 522 will show that it differs from Nesospiza in the formation of the bill.

\section{IONORNIS MARTINICA (L.). American Purple Gallinule.}

In Bull. B.O.C. xliv, p. 72, 1924, Dr. Percy R. Lowe records that he had received at the British Museum, from the Rev. H. M. C. Rogers, an immature example of this bird, which had been taken on the island of Tristan da Cunha. This is the first record for the island. A second example is recorded by Stenhouse in the Scottish Naturalist for 1924, p. 96.

In the Birds of Massachusetts, vol. i, November 1925, p. 364, Forbush has given a good description, and on pl. 24 a coloured figure of the adult in breeding plumage. He says that it breeds in swamps and marshes, and the nest is a platform of rushes, etc., like a shallow basket suspended among, and woven into, marsh vegetation.

Eggs.-Clutch 6 to 10, soiled white, creamy or pale buff, sparsely spotted, chiefly about the larger end with brown, umber and neutral tints. They measure $1 \cdot 63-1 \cdot 54 \times 1 \cdot 16-1 \cdot 13$ inches.

Breeding season, April to June (October).

Incubation period, 23 to 25 days.

In the "Life Histories of North American Marsh Birds," Bulletin 135, p. 339, 1926, A. C. Bent gives a delightful account of this bird. He says that the clutch is 6 to 8 , usually ovate in shape, and the shell is smooth with little or no gloss. Pale cinnamon-pink or pale pinkish buff to cartridge-buff. They are lightly and unevenly marked, with very small spots and fine dots of bright browns and pale drabs. Average measurements of 56 eggs, $39 \cdot 2 \times 28 \cdot 8$. Extremes, $42 \cdot 7$ $\times 30 \cdot 2,39 \times 30 \cdot 2$ and $34 \cdot 6 \times 26 \cdot 2$.

Breeding months, April, May and June.

[Two have been obtained at Tristan, and seem to be the only specimens recorded from the Aethiopian Region.

An immature specimen of this species was included among the skins sent me in 1919. It was obtained (date not recorded) by Tom Rogers, who wrote: "It is the only one we ever saw on the island, and I only got it by chance when going to the other side of the island called the 'Rooky.' I did not have a gun, but knocked it down with a stone." A second specimen, also immature, was obtained by the Rev. H. M. Rogers at Tristan, and is now in the British Museum.

These birds must be " some travellers," when immature specimens can cross the 2,000 miles of ocean to Tristan.] 


\section{$2 \mathrm{BHL}$ Biodiversity Heritage Library}

1932. "The Birds of Tristan da Cunha, with notes by J. G. Gordon." Novitates zoologicae : a journal of zoology in connection with the Tring Museum 38, 13-48. https://doi.org/10.5962/bhl.part.14741.

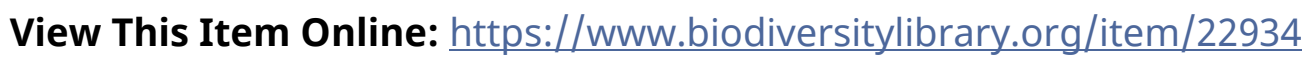

DOI: https://doi.org/10.5962/bhl.part.14741

Permalink: https://www.biodiversitylibrary.org/partpdf/14741

\section{Holding Institution}

Natural History Museum Library, London

\section{Sponsored by}

Natural History Museum Library, London

\section{Copyright \& Reuse}

Copyright Status: In copyright. Digitized with the permission of the rights holder.

Rights Holder: The Trustees of the Natural History Museum, London

License: http://creativecommons.org/licenses/by-nc-sa/4.0/

Rights: http://biodiversitylibrary.org/permissions

This document was created from content at the Biodiversity Heritage Library, the world's largest open access digital library for biodiversity literature and archives. Visit BHL at https://www.biodiversitylibrary.org. 